\title{
Physiological and pathological implications of retinoid action in the endometrium
}

\author{
Yanwen Jiang', Lu Chen', Robert N Taylor ${ }^{2}$, Chunjin Li,** and Xu Zhou',** \\ ${ }^{1}$ College of Animal Sciences, Jilin University, Changchun, Jilin, China \\ 2Departments of Obstetrics and Gynecology and Molecular Medicine and Translational Sciences, Wake Forest School of Medicine, Winston-Salem, \\ North Carolina, USA \\ Correspondence should be addressed to X Zhou or C Li: xzhou65@vip.sina.com or Ilcjj158@163.com
}

*(C Li and X Zhou contributed equally to this work)

\section{Abstract}

Retinol (vitamin A) and its derivatives, collectively known as retinoids, are required for maintaining vision, immunity, barrier function, reproduction, embryogenesis and cell proliferation and differentiation. Despite the fact that most events in the endometrium are predominantly regulated by steroid hormones (estrogens and progesterone), accumulating evidence shows that retinoid signaling is also involved in the development and maintenance of the endometrium, stromal decidualization and blastocyst implantation. Moreover, aberrant retinoid metabolism seems to be a critical factor in the development of endometriosis, a common gynecological disease, which affects up to $10 \%$ of reproductive age women and is characterized by the ectopic localization of endometrial-like tissue in the pelvic cavity. This review summarizes recent advances in research on the mechanisms and molecular actions of retinoids in normal endometrial development and physiological function. The potential roles of abnormal retinoid signaling in endometriosis are also discussed. The objectives are to identify limitations in current knowledge regarding the molecular actions of retinoids in endometrial biology and to stimulate new investigations toward the development potential therapeutics to ameliorate or prevent endometriosis symptoms.

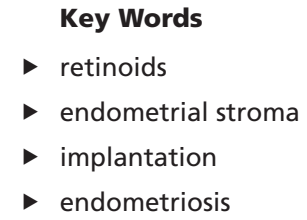

Journal of Endocrinology (2018) 236, R169-R188

\section{Introduction}

In many species, such as human, nonhuman primates and rodents, the endometrium consists of epithelial glands supported by a connective tissue stroma that undergoes cycles of proliferation and secretory activity. The uterine mucosa proliferates under the influence of estrogen. However, after ovulation, luteal progesterone changes the proliferative pattern to a secretory pattern that includes decidualization of endometrial stromal cells, which provides the nutritive and immune-privileged matrix for embryo implantation (Gellersen \& Brosens 2014) and prevents the malignant transformation of endometrial epithelium under unopposed estrogenic action (Cheng et al. 2008). Though progesterone is critical for the initiation and maintenance of decidualization in the estrogen-primed endometrium, other factors, including prostaglandins, prolactin, growth factors and extracellular matrix proteins, are important.

Retinoic acid (RA), the physiological active metabolite of vitamin A (retinol), controls multiple biological processes, including differentiation, apoptosis and cell survival, via its nuclear receptors RARs or nonclassical RA receptor peroxisome proliferator-activated 
receptor $\beta / \delta(\operatorname{PPAR} \beta / \delta)$. The pathway of $\mathrm{RA}$ is also considered to be involved in the proliferation of epithelia and the transformation of endometrial stromal cells into specialized decidual cells. Numerous studies have demonstrated that the distribution of RA (Zheng et al. 2000), as well as the expression of RA receptors (Fukunaka et al. 2001, Ozaki et al. 2017), cellular retinol and RA-binding proteins (CRBP1, CRABP1 and CRABP2; Zheng \& Ong 1998, Zheng et al. 2000), RA-synthesizing enzymes ALDH1A1 and ALDH1A2 (Napoli 1999, Duester 2000), and the RA-catabolizing enzyme CYP26A1 (Vermot et al. 2000) are highly and differentially regulated in the differentiating endometrium during the ovarian cycle and during the phase of blastocyst implantation (Vermot et al. 2000, Zheng 2000, Ozaki et al. 2017). The expression of these same genes can be modulated by ovarian steroid hormones (i.e., estradiol and progesterone) treatment (Vermot et al. 2000, Li \& Ong 2003, Rühl et al. 2006, Fritzsche et al. 2007). The retinoid pathway is known to play vital roles in endometrial development and differentiation (Tanmahasamut \& Sidell 2005, Wu et al. 2013, Nakajima et al. 2016), as well as endometrial neovascularization (Sidell et al. 2010) and blastocyst implantation (Han et al. 2010, Xia et al. 2010, Ma et al. 2012).

In addition, accumulating evidence shows that an aberrant RA metabolism can be a critical factor in the development of endometriosis (Pavone et al. 2011, Wieser et al. 2012, Pierzchalski et al. 2014, Yamagata et al. 2015), a common gynecological disease that affects up to $10 \%$ of reproductive-age women. This disease is characterized by the ectopic localization of endometrial-like tissues in the pelvic cavity, and its pathogenesis involves uncontrollable cell proliferation and is associated with local invasion and distant metastasis. Among the numerous aspects of endometrial behavior regulated by RA are matrix metalloproteinase secretion, gap junctional intracellular communication and the production of various cytokines involved in stromal cell growth, adhesion and differentiation (Wu et al. 2013). Interleukin 6 (IL-6), monocyte chemotactic protein 1 (MCP-1), tumor necrosis factor $\alpha(\mathrm{TNF}-\alpha)$, vascular endothelial growth factor (VEGF) and connexin43 are all aberrantly expressed in endometriotic lesions (Sawatsri et al. 2000, SharpeTimms 2001, Nozaki et al. 2006, Sidell et al. 2010, Wu et al. 2013). Thus, many seemingly discordant features of endometriosis, including decreased cell death, increased growth and migration, inflammation and enhanced invasive properties of intraperitoneally seeded endometrial cells, might be accounted for by the dysregulation of RA signaling. This contention was recently supported in a mouse model of endometriosis where treatment with RA suppressed IL- 6 and the establishment, growth and vascularity of peritoneal implants, promoted macrophage differentiation (Wieser et al. 2012).

RA plays fundamental roles in the normal maintenance of endometrial physiology (Zheng et al. 2000, Sidell et al. 2002, Ding et al. 2003, Kuroda et al. 2013), and aberrant RA metabolism might be a predisposing factor for the development of endometriosis (Pavone et al. 2011, Wieser et al. 2012, Pierzchalski et al. 2014, Yamagata et al. 2015). However, a comprehensive and systematic analysis and understanding of RA pathway in endometrial physiology and pathology remain lacking. In this review, the latest advances with regard to understanding the retinoid pathway are first discussed, followed by an assessment of the functional roles of this signaling network in endometrial development and physiological function. This review also summarizes evidence that supports fundamental defects in retinoid metabolism and action among women with endometriosis. The objectives are to identify limitations in our current knowledge regarding molecular retinoid actions in endometrial biology and to propose future investigations to develop therapeutic or preventative agents for clinical endometriosis management.

\section{Retinoid metabolism and signaling}

Retinol (vitamin A) is a lipid-soluble vitamin that cannot be synthesized de novo by animals and is obtained from the diet as either preformed retinoids or carotenoids within the intestine. In the enterocytes, proretinoid carotenoids, such as $\beta$-carotene, can be either cleaved and converted to retinoids or incorporated intact and unmodified along with dietary fat and cholesterol into chylomicrons. Dietary retinoids that are newly absorbed by the enterocytes are esterified to retinyl ester and packaged with dietary fat and cholesterol into chylomicrons, which are later secreted into the lymphatic system. Approximately 66\%-75\% of newly acquired retinoids are absorbed and stored in the liver as lipid droplet retinyl esters (Harrison 2005). The remainder is absorbed by extrahepatic tissues (Quadro 2004). In cases of dietary vitamin A deficiency, the stored retinoid is hydrolyzed and mobilized back to retinol, which can be bound by RBP4 and enter the bloodstream for transport to peripheral tissues. In blood, holo-RBP4 is bound to transthyretin (TTR), a carrier protein for thyroid hormones. In a fasting circulation, retinol-RBP4 
is the preponderant retinoid form comprising $>95 \%$ of retinoids, whereas, after a retinoid-rich meal, chylomicron retinyl ester concentrations exceed those of retinol-RBP4. In extrahepatic tissues, retinoids are acquired from the circulation in the form of carotenoids and retinyl esters from chylomicrons and retinol from retinol-RBP4-TTR ternary complexes. The uptake of retinol from retinolRBP4-TTR into cells is mediated by the transmembranespanning protein stimulated by retinoic acid 6 (STRA6), which acts as a high-affinity cell surface receptor that binds extracellular holo-RBP, facilitates the dissociation of retinol from its carrier and transports it into cells (Kawaguchi et al. 2007, 2015).

Within target cells, carotenoids and retinyl esters can be both converted into retinol, which binds cellular retinol-binding proteins (CRBP1 and CRBP2).
Cellular retinol can be stored in the form of retinyl ester catalyzed by lecithin: retinol acyltransferase (LRAT) or converted into transcriptionally active RA metabolites via two enzymatic reactions. First, retinol is converted into retinaldehyde by alcohol dehydrogenases (ADHs) or retinol dehydrogenases (RDHs) (Fig. 1). Aldehyde dehydrogenases (ALDHs) then catalyze the conversion of retinaldehyde into RA (Conaway et al. 2013). In the retinal pigment epithelium of the eye, retinol can also be metabolized to 11-cis-retinal, which serves to regenerate the visual pigment rhodopsin.

Most of the physiologic actions of retinoids are accounted for by the transcriptional regulatory activity of physiological active metabolites, i.e., all-trans-retinoic acid (atRA or RA) and 9-cis retinoic acid (9cRA). The action of RA is mediated by nuclear receptors, RA receptors

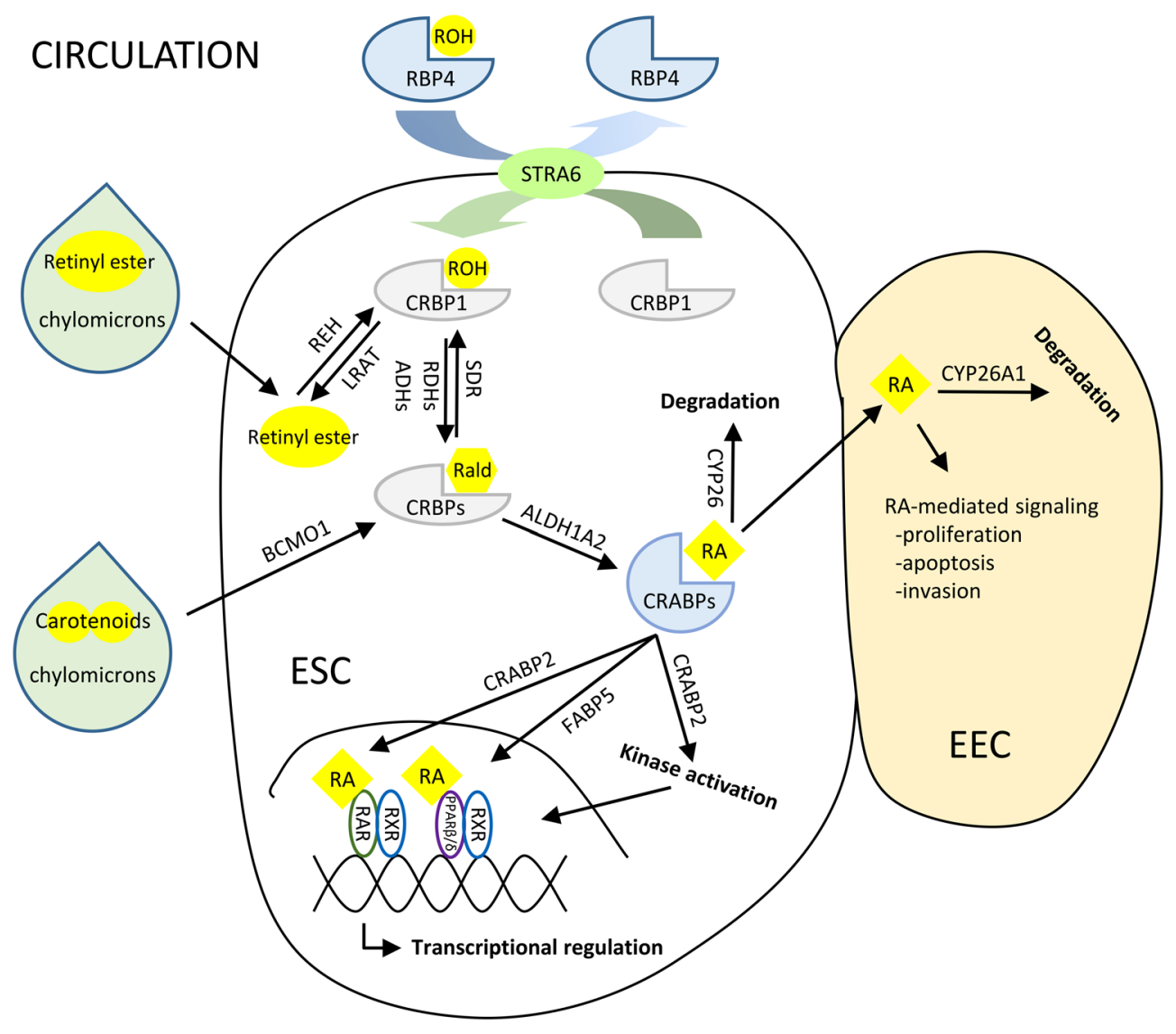

Figure 1

Schematic representation of retinoid uptake, metabolism and signaling in endometrial stromal cells (ESC) and endometrial epithelial cells (EEC). ESC can take up retinoids from the circulation in the forms of retinyl esters in chylomicrons (following a retinoid-rich meal), RBP4-bound retinol (ROH) (during fasting) or albumin-bound RA (very low levels). The transport of retinol from retinol-RBP4 into ESC is mediated by STRA6; however, the cellular processes that mediate retinyl ester and RA uptake are not yet established. Carotenoids in chylomicrons also represent a source of retinoids and can be converted to retinal (Rald) by $\beta$-carotene-15, 15'-monooxygenase (BCMO1). Cellular retinol can be oxidized to retinal and RA by dehydrogenases (ADHs, RDHs and ALDHs) or be converted to retinyl ester, a retinoid storage form, catalyzed by LRAT. Retinyl esters can also be hydrolyzed to retinol catalyzed by retinyl ester hydrolase (REH). RA exerts autocrine and paracrine transcriptional regulatory effects through RARs, RXRs and PPAR $/ \delta$ or alternatively degraded by CYP26 enzymes in ESC and neighboring EEC. A full colour version of this figure is available at https://doi.org/10.1530/JOE-17-0544. 
(RARs): RAR $\alpha, \operatorname{RAR} \beta$ and RAR $\gamma$ or peroxisome proliferatoractivated receptor $\beta / \delta(\operatorname{PPAR} \beta / \delta)$. In conjunction with transcriptional coactivators and corepressors, RARs and PPARs heterodimerize with retinoid $X$ receptors (RXRs: RXR $\alpha, \operatorname{RXR} \beta$ and RXR $\gamma$ ) and associate with RA response elements (RAREs) or peroxisome proliferator response elements (PPREs) in the regulatory regions of specific target genes to regulate target gene transcription (Chambon 2005, Schug et al. 2008, Al Tanoury et al. 2013, RochetteEgly 2014). RA partitioning between the two receptor signaling cascades has opposing effects on cell growth and apoptosis and the alternative pathways are regulated by the ratio of intracellular lipid-binding proteins, cellular RA-binding protein (CRABP2) and fatty acid-binding protein (FABP5; Schug et al. 2007). CRABP2 and FABP5 can bind and transport RA to RARs and PPAR $\beta / \delta$, respectively (Delva et al. 1999, Dong et al. 1999). Furthermore, besides classical nuclear receptor signaling, RA stimulates rapid nongenomic signaling events through the stimulation of kinase phosphorylation by extra-nuclear RARs, which also can affect gene transcription (Al Tanoury et al. 2013, Rochette-Egly 2014). The primary biological ligand for RARs is atRA, whereas 9cRA can bind to RARs and RXRs.

The tissue distribution and levels of RA are regulated through its synthesis by ALDHs (Lin et al. 2003) and its catabolism into inactive polar compounds by CYP26 enzymes (Chithalen et al. 2002, Conaway et al. 2013). CRABPs and FABP5 also participate in the regulation of RA concentration (Dong et al. 1999, Noy 2000) and metabolism (Delva et al. 1999, Dong et al. 1999, Napoli 2016). In RA-sensitive tissues, CRABP1 can protect these vulnerable areas against the toxic effects of excessive amounts of RA (Ruberte et al. 1992). Furthermore, many of the components of RA biosynthesis are controlled by atRA via negative feedback. ATRA induces its own catabolism by inducing CYP26 transcription, allowing the degradation of excess atRA. Conversely, atRA can also regulate its biosynthesis by positive feedback, upregulating the expression of several RA biosynthesis components, such as RBP4, CRBP1 and STRA6 (Wu \& Ross 2010).

\section{Retinoid action in endometrial development and physiological function}

The mammalian uterus develops from fused paramesonephric (Müllerian) ducts during embryonic development. The adult mammalian endometrium is divided into two steroid-responsive compartments, namely, an epithelial compartment consisting of luminal and glandular epithelia and a stromal compartment filled with fibroblasts, microvascular cells, macrophages and perivascular and large granular lymphocytes that infiltrate the stroma during the luteal phase of the menstrual cycle (Punyadeera et al. 2003). Luminal epithelium is the first point of contact between the uterus and blastocyst during implantation, while glandular epithelia synthesize and secrete bioactive substances that contribute to uterine receptivity and stromal cell decidualization. The endometrial functional layer undergoes cyclic regeneration regulated by estradiol and progesterone during menstrual or estrous cycles. It initially proliferates under the influence of estrogen. However, after ovulation, in addition to estradiol, the ovary starts to produce progesterone, which changes the proliferative pattern to a secretory one, providing a suitable environment for blastocyst implantation. Following fertilization, the embryo implants into the uterine wall and trophoblast-derived gonadotropins support the pregnancy by maintaining corpus luteum production of progesterone and estradiol. In this case, the endometrial functional layer remains as decidua. If fertilization or implantation fails, the endometrium will be either remodeled (estrous cycle) or shed (menstrual cycle). Numerous factors are involved in the regulation of endometrial development and function and RA plays important roles in these processes.

\section{Hormonal control of endometrial retinoid pathway}

Numerous studies revealed that the retinoid pathway and distribution of RA are distinctly and highly regulated in human and rodent endometrial epithelium and stroma (Vermot et al. 2000, Rühl et al. 2006, Fritzsche et al. 2007). The biosynthesis of endogenous RA is catalyzed directly by ALDHs. Among them, ALDH1A1 (also known as RALDH1) and ALDH1A2 (also known as RALDH2) exhibit specific temporal and special expression patterns in human and rodent endometrium during the ovarian cycle and early pregnancy. The abundance of Aldh1a1 mRNA increases during murine diestrus and proestrus, whereas Aldh1a2 is highly induced in metestrus (Vermot et al. 2000). The tissue localization of ALDH1A1 and ALDH1A2 showed that $A L D H 1 A 1$ and $A L D H 1 A 2$ are expressed in glandular epithelial and stromal cells, respectively (Vermot et al. 2000). The highest Aldh1a2 expression in mouse stromal cells is observed during the estrogenic phase of the estrous cycle, strongly suggesting that its endogenous expression is estrogen dependent. This speculation was confirmed by subsequent studies in the endometrium of mice, rats and 
Table 1 Upregulated and downregulated genes involved in retinoid metabolism and signaling by estrogen and/or progesterone in the endometrium.

\begin{tabular}{|c|c|c|c|c|c|c|}
\hline Genes & $\mathbf{E}_{\mathbf{2}}$ & $\mathbf{P}_{4}$ & $E_{2}+P_{4}$ & Cell type & Species & References \\
\hline$A L D H 1 A 1$ & $\downarrow^{a}$ & - & & Epithelium & Mouse & Vermot et al. (2000), Rühl et al. (2006) \\
\hline$A L D H 1 A 2$ & $\uparrow b$ & - & $\uparrow$ & Stroma & Human, mouse, rat & $\begin{array}{l}\text { Vermot et al. (2000), Deng et al. (2003), } \\
\text { Li et al. (2004), Rühl et al. (2006) }\end{array}$ \\
\hline CYP26A1 & $-c$ & $\uparrow$ & $\uparrow$ & Epithelium & Mouse & Fritzsche et al. (2007) \\
\hline$C R A B P 2$ & $\uparrow$ & d & & Epithelium & Mouse, rat & Wardlaw et al. (1997), Li \& Ong (2003) \\
\hline$R A R \alpha$ & $\uparrow$ & & & Epithelium & Rat & Boehm et al. (1997) \\
\hline$R A R \gamma$ & $\uparrow$ & & & Epithelium & Rat & Boehm et al. (1997) \\
\hline$R \times R \alpha$ & $\uparrow$ & & & Epithelium & Rat & Boehm et al. (1997) \\
\hline
\end{tabular}

aDownregulation; bupregulation; cno effect; d(blank) remains to be established.

$\mathrm{E}_{2}$, estradiol; $\mathrm{P}_{4}$, progesterone.

humans (Deng et al. 2003, Li et al. 2004, Rühl et al. 2006). Using ovariectomized mouse models, Rühl et al. (2006) demonstrated that $A L D H 1 A 2$ expression is rapidly (within $1-4 \mathrm{~h}$ ) induced in stromal cells by estradiol but not by progesterone. By contrast, estradiol, but not progesterone, treatment decreases (within 4-24h) ALDH1A1 expression levels in glandular epithelium (Rühl et al. 2006). In a study by Deng et al. (2003), ALDH1A2 expression was induced within human endometrium by estrogen replacement therapy. Thus, estradiol stimulates $A L D H 1 A 2$ expression in endometrial stroma but suppresses ALDH1A1 expression in the endometrial glandular epithelium. By contrast, progesterone neither induces nor reduces the expression levels of the two genes (Table 1). The selective effects of estradiol are due to the differential expression of estrogen nuclear receptor isotypes ER $\alpha$ and ER $\beta$ (Katzenellenbogen $\&$ Korach 1997). In rat uteri, ER $\alpha$ is principally expressed in luminal and glandular epithelia, whereas ER $\beta$ is predominantly expressed in the stroma (Mowa \& Iwanaga $2000 a, b)$. As ALDH1A2 expression might be selectively regulated via ER $\beta$, further study should focus on using ER $\alpha / E R \beta$-selective ligands to dissect these estrogenregulated pathways in the regulation of $A L D H$ expression. Meanwhile, a potential estrogen response element was observed in the promoter of the mouse Aldh1a2 gene (Wang et al. 2001). However, whether it plays a functional role remains unknown.

In addition to RA-synthesizing enzymes, RA levels are also regulated by RA-catabolizing enzymes, particularly the CYP26 family. These enzymes catalyze the conversion of RA into less-active polar metabolites (Conaway et al. 2013). CYP26A1, one of the most important members of the CYP26 family, is expressed in female reproductive tract (Vermot et al. 2000). In endometrial tissue obtained from premenopausal women, the CYP26A1 mRNA levels were approximately 20 times higher during the late secretory phase than in the proliferative phase (Deng et al. 2003).
In mouse endometrium, although CYP26A1 expression is undetectable during the normal ovarian cycle, it is strongly induced in luminal and glandular epithelia, $4 \mathrm{~h}$ after progesterone administration (Fritzsche et al. 2007) or $24 \mathrm{~h}$ after human chorionic gonadotrophin (hCG) administration (Vermot et al. 2000). Also, in mouse endometrial epithelium, Cyp26a1 expression is strongly induced between 3.5 and 4.5 gestational days, i.e., when the developing blastocysts implant into the endometrium. Endometrial Cyp26a1 expression can be mainly regulated by progesterone because not only Cyp26a1 mRNA levels are strongly increased in uterine luminal and glandular epithelial cells by the administration of progesterone or the combination of progesterone and estradiol but also the simultaneous administration of an antiprogestin inhibits the gene expression (Fritzsche et al. 2007) (Table 1). This regulation of Cyp26a1 expression by progesterone may occur through direct activation of the progesterone receptor. RU486 (also known as mifepristone) is a synthetic steroid that exerts antiprogesterone action by competing with progesterone for receptor binding (Chan et al. 2003). Treatment with either RU486 or the combination of RU486 and progesterone showed an inhibition of Cyp26a1 expression (Fritzsche et al. 2007). The mouse Cyp26a1 promoter and its regulatory regions were partially characterized by Loudig and coworkers (2000, 2005). Their study showed the presence of two RA response elements on the Cyp26a1 promoter, but no consensus binding sites for progesterone receptors. Thus, further studies are necessary to identify the possible regulatory elements responsible for the progesterone control of Cyp26a1 expression.

Several binding proteins involved in the retinoid pathway are also distinctive in rodent and human endometria during the ovarian cycle (Loughney et al. 1995, Wardlaw et al. 1997). Crbp1 expression peaked during diestrus, whereas Crabp2 expression peaked 
sharply during estrus (proliferative phase). In addition, Crabp2 expression has been shown to be induced directly by estradiol administration in the uteri of ovariectomized rats (Li \& Ong 2003) (Table 1). Immunohistochemical studies showed that CRABP2 is localized to the luminal epithelium, whereas CRBP1 in the stroma (Wardlaw et al. 1997). CRABP2 expression is associated with local RA levels (Bucco et al. 1997, Zheng et al. 2000). From these data, it can be concluded that the endometrial stroma upregulates ALDH1A2 and therefore RA production upon estrogen stimulation. RA then diffuses into the adjacent epithelium, where it is catabolized by CYP26A1 induced by progesterone during the late secretory phase or implantation.

Numerous studies demonstrated the expression of RARs and RXRs in human endometrial epithelial and stromal cells (Prentice et al. 1992, Loughney et al. 1995, Kumarendran et al. 1996, Fukunaka et al. 2001). Using Northern blot, Kumarendran et al. (1996) demonstrated that RAR $\beta$ mRNA expression is 1.7-fold higher in epithelial samples from the proliferative phase than from the secretory phase. Meanwhile, no significant difference was observed between the expression levels of $R A R \alpha, R A R \gamma$ and RXR $\alpha$ mRNA in epithelial tissues in the proliferative phase and those in the secretory phases. Similarly, the expression of $R A R \alpha, R A R \beta, R A R \gamma$ and $R X R \alpha$ mRNA in human endometrial stroma did not change in the proliferative and secretory phases of the menstrual cycle (Kumarendran et al. 1996). Meanwhile, using immunohistochemistry and Western blot analysis, Fukunaka et al. (2001) investigated changes in expression and subcellular localization of RARs and RXRs in human endometrial epithelium during the menstrual cycle. Their results indicated that, in the nuclei of endometrial epithelia, RARs and RXRs are expressed strongly in the proliferative phase and reduced during the secretory phase, correlated with serum estradiol concentration and ER expression (Fukunaka et al. 2001). Although RXRs decrease during the secretory phase, they are still expressed in the nuclei in the late secretory phase; by contrast, RARs are infrequently detected in the midsecretory and late secretory phases (Fukunaka et al. 2001). In stromal cells, the intensity of staining is strong in the proliferative phase but decreases in the secretory phase. Meanwhile, immunoreactivity to RXRs is strong throughout the cycle, similar to that in the nuclei of the epithelial cells (Fukunaka et al. 2001). In addition, $\mathrm{ER} \alpha$ shows more intense staining in the endometrium of the proliferative phase, and PR shows positive staining in the endometrium of the mid-proliferative and early secretory phases (Fukunaka et al. 2001). The expression of retinoid receptors is associated with serum estradiol concentration and ER expression. Consistently, data from Boehm et al. (1997) showed that RAR $\alpha, \operatorname{RAR} \gamma$ and RXR $\alpha$ expression levels are increased by estrogen in rat endometrial epithelium (Table 1). Thus, the expression of RARs is strongly affected by serum estrogen via ER in the endometrium. However, whether progesterone or PR expression inhibits the expression of retinoid receptors in endometrium remains to be determined.

Therefore, the endometrial retinoid pathway is mainly under the influence of ovarian steroid hormones, and RA and its receptors have regulatory effects on the endometrium during the ovarian cycle (Fig. 2).

\section{Retinoid action in endometrial differentiation and development}

\section{Fate determination of endometrium in Müllerian duct}

During development, the Müllerian ducts persist in females and differentiate into morphologically and functionally distinct oviducts, uterus and vagina. The oviductal epithelia are composed of ciliated cells and secretory cells (Yamanouchi et al. 2010); the uterine epithelia consist of simple columnar luminal and glandular epithelia (Kurita et al. 2000) and the vaginal epithelium

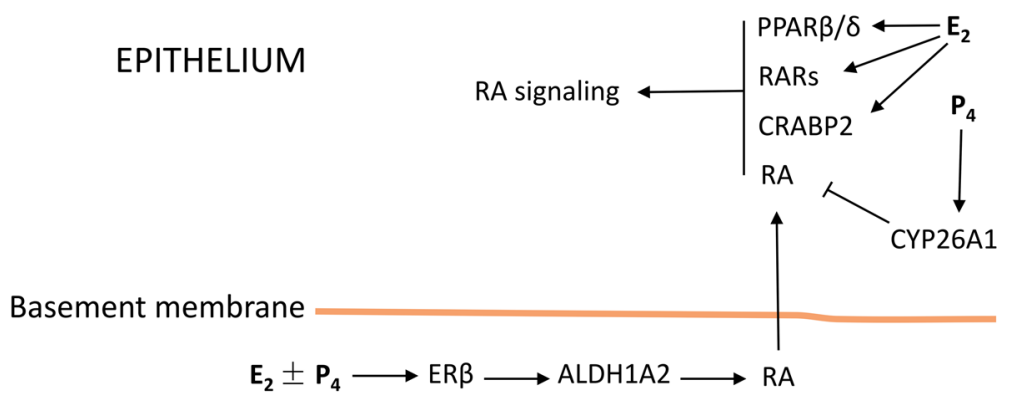

STROMA
Stimulatory modification Inhibitory modification
Figure 2

Hormonal control of the retinoid pathway in the endometrium. Estradiol $\left(E_{2}\right)$ or $E_{2}+$ progesterone $\left(P_{4}\right)$ can stimulate the expression of ALDH1A2, which can promote RA production, in stromal cells. RA produced by ESC can diffuse to EEC, where $E_{2}$ can promote the expression of RARs, $P P A R \beta / \delta$ and CRABP2. Thus, $E_{2}$ can increase RA signaling in the endometrium. However, $\mathrm{P}_{4}$ can inhibit RA signaling through inducing CYP26A1 expression in EEC. A full colour version of this figure is available at https://doi.org/10.1530/ JOE-17-0544. 
develops into stratified cuboidal epithelium (Nakajima et al. 2011a). Nakajima et al. (2011a) performed tissue recombination experiments with epithelium and stroma to investigate the mechanisms underlying differentiation of the Müllerian ducts. The data showed that stromal factors determine the fate, differentiation and growth of Müllerian duct epithelia into the oviducts, uteri and vaginas of mice. DNA microarray analysis showed that the expression of several genes involved in retinoid metabolism is greater in the uteri than in the vaginas of neonatal mice (Suzuki et al. 2006, 2007). When pregnant rats are fed with a vitamin A-deficient diet, their fetuses exhibit incomplete Müllerian development (Wilson \& Warkany 1948). Furthermore, Müllerian ducts of RAR or RXR KO mice are absent at embryonic day 12.5 (E12.5) (Mendelsohn et al. 1994, Kastner et al. 1997). These data suggest that retinoid signaling through RAR is essential for Müllerian duct development.

The important role of the retinoid pathway in fetal uterine stroma development was identified in the mouse. In fetal mice, Rdh10 and Aldh1a2 are expressed in the stroma of proximal Müllerian ducts, with expression levels decreasing toward the caudal ends (Nakajima et al. 2016). RDH10 is the primary enzyme responsible for catalyzing the conversion of retinol to retinaldehyde, the first step of RA synthesis, in embryonic mice (Farjo et al. 2011). Uterine Cyp26a1 expression is essential for blastocyst implantation in pregnant mice (Han et al. 2010). However, Cyp26a1 expression levels are low in Müllerian ducts, suggesting RA is not degraded there and more RA accumulates. Thus, RA levels might be increased in proximal Müllerian ducts. This hypothesis was confirmed in a reporter mouse expressing lacZ regulated by a strong RARE in the promoter. The data demonstrated that the highest endogenous RA levels are in the proximal Müllerian duct stroma, and the levels gradually decrease from the proximal to caudal regions (Nakajima et al. 2016). Thus, RA is produced and acts in the stroma of proximal and middle Müllerian ducts. Rdh10 and Aldh1a2 expression are significantly higher in the uteri of postnatal mice than those in their vaginas from postnatal day 2 (P2) to P90 (Nakajima et al. 2016). Moreover, mice fed from birth with vitamin A-deficient diets for 10 or 14 weeks exhibit squamous metaplasia in their uterine epithelia (Darwiche et al. 1993, Jetten et al. 1996). These data suggest a critical role of RA signaling in maintaining uterine epithelium.

In organ-cultured Müllerian ducts of RARE-lacZ mice at E14.5 and E17.5, retinal or RA treatment stimulated RA signaling in the stroma and induced uterine epithelial differentiation, which was defined as a layer of columnar epithelial cells negative for oviductal and vaginal epithelial markers. By contrast, inhibition of RAR signaling with the pan-RAR antagonist AGN193109 (AGN; Nakajima et al. 2016) induces vaginal epithelial differentiation. Nakajima et al. (2016) cultured Müllerian duct explants at E14.5 or E17.5 with RA or RAR antagonists and grafted these under the renal capsules of host mice. At day 30 post grafting, control E14.5 Müllerian ducts developed oviductal and uterine epithelia, while AGN treatment irreversibly induced vaginal epithelia. Meanwhile, grafted E17.5 middle Müllerian ducts had only uterine epithelia, and AGN treatment irreversibly induced vaginal epithelia. In grafted E17.5 caudal Müllerian ducts, vaginal epithelia were observed, and RA treatment permanently induced uterine epithelia but did not induce oviductal epithelia. These data indicate that RA in stroma at developing stages induces uterine epithelia in Müllerian ducts, whereas the inhibition of RAR signaling induces vaginal epithelia. The fate of oviductal stroma is determined at E14.5 (Nakajima et al. 2016). In female mouse embryos, activin A induced by inhibin $\beta A$ is essential for the differentiation of vaginal epithelia (Nakajima et al. 2011b), whereas RA inhibits inhibin $\beta A$ expression in the urogenital sinus (Bryant et al. 2014). Hoxa10 is expressed at the boundary between future uterine and oviductal stroma in the Müllerian ducts at E16.5 (Ma et al. 1998) and is connected with the determination of the borderline between oviduct and uterus (Benson et al. 1996). RA stimulates Hoxa10 and Hoxa11 expression in Müllerian ducts; however, AGN abolishes these. Although the Hoxa10 promoter contains a RARE (Delacroix et al. 2010), RAR cannot bind to the predicted RARE in the Müllerian duct (Nakajima et al. 2016). Thus, RA seems to induce Hoxa10 expression via indirect RAR signaling, and other factors might mediate the action of RA on the determination of the border between the uterine and vaginal stroma. These data support a model in which RA-RAR signaling can play a crucial role in the determination of the fate of epithelia and stroma in the female reproductive tract (Fig. 3).

\section{Endometrial gland development}

Uterine glands are essential for pregnancy on account of secreting or transporting bioactive substances that regulate uterine receptivity and blastocyst implantation. Uterine gland development or adenogenesis is a postnatal event in rodents, domestic animals and humans (Hu et al. 2004). At birth, murine uteri lack uterine glands and consist of simple luminal epithelium supported by undifferentiated mesenchyme. Between P0 and P9, glandular epithelial 
Uterine epithelium

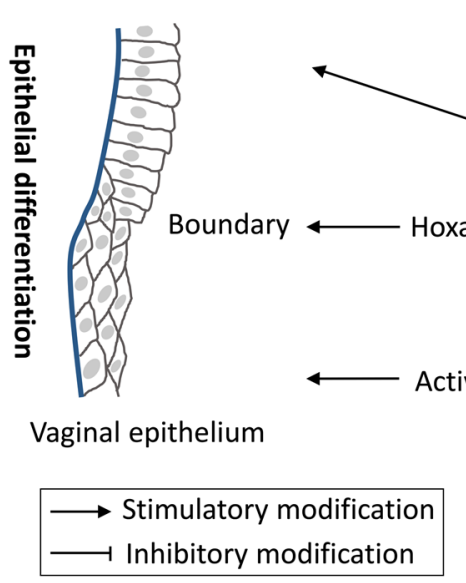

cells differentiate and bud from luminal epithelia. By P15, the uterine histoarchitecture resembles that of the adult (Spencer et al. 2012). Gland morphogenesis also occurs during endometrial regeneration following menses or parturition (Garry et al. 2010, Huang et al. 2012). Based on data from the available literature, the luminal and glandular epithelia of mouse uteri have common but distinctly expressed genes (Cha et al. 2012, Filant \& Spencer 2013). The components of the retinoid pathway, including Aldh1a1, Aldh1a3, Rdh1 and Rdh10, are enriched in the glandular epithelia of neonatal uteri. Through microarray analysis, the glandular epithelium-enriched genes in P10 uteri were found to be associated with branching morphogenesis, growth and RA biosynthesis. Aldh1a1 is enriched in developing neonatal and adult endometrial glands (Filant \& Spencer 2013). Furthermore, the expression levels of Aldh1a1 and Aldh1a3 on P10 are much lower in progesterone-induced uterine glandknockout (PUGKO) mice than in control mice (Filant \& Spencer 2013). In addition, retinyl palmitate increases glandular epithelial areas in the uteri of neonatal pigs treated for 14 days starting from birth (Vallet et al. 1995). These data suggest that the retinoid pathway is involved in uterine adenogenesis. Further studies are still needed to elucidate the functional role of the retinoid pathway and the mechanisms governing uterine adenogenesis in neonates. The involvement of RA signaling in postnatal mouse endometrial adenogenesis will require conditional postnatal deletion models, such as the PR-Cre system.

\section{Endometrial proliferation}

Ovarian estrogen induces the proliferation of epithelial cells and stromal fibroblasts during the pre-ovulatory

\section{Figure 3}

Schematic representation of retinoid action in endometrial development and physiological function. RA signaling in the Müllerian duct determines the differentiation of epithelium to form the future uterus and vagina involving Hoxa10, inhibin $\beta A$ and activin A. Besides, RA signaling stimulates endometrial GJIC formation through inducing $\mathrm{Cx} 43$ expression and neovascularization through inducing VEGF expression. RA prevents stromal cell decidualization through inhibiting PRL, IGFBP1 and HSD11B1 production and promotes maintenance of fibronectin, an indicator of the undifferentiated stromal phenotype. In addition, RA reduces factors like LIF and HB-EGF1, which are required for endometrial receptivity, and successful implantation during late secretory phase requires lower RA levels in the luminal epithelia. A full colour version of this figure is available at https://doi.org/10.1530/JOE-17-0544.

phase (Punyadeera et al. 2003). Studies in rodents suggested that RA plays an important role in modulating the effects of estrogen on the endometrium. As discussed earlier, endometria upregulate $A L D H 1 A 2$ upon estrogen stimulation during the proliferative phase (Vermot et al. 2000, Deng et al. 2003, Rühl et al. 2006). Furthermore, the expression levels of RA receptors (Fukunaka et al. 2001) and CRABP2 (Loughney et al. 1995, Wardlaw et al. 1997, Li \& Ong 2003), which bind and deliver RA to nuclear RAR, are stimulated by estradiol in the proliferative phase in epithelial and stromal cells. These data suggest that estrogen coordinately upregulates RA production, transport and signaling in the proliferative phase of the ovarian cycle. This coordinated mechanism may play a role in antiproliferative effects that counterbalance estrogeninduced endometrial proliferation. Studies on vitamin A-deficient rats demonstrated that physiologic levels of RA suppress endometrial hyperplasia and metaplasia associated with chronic estrogen administration (Bo \& Smith 1966). In addition, pharmacological doses of RA in immature ovariectomized rat suppress estrogeninduced endometrial cell proliferation (Boettger-Tong \& Stancel 1995, Loughney \& Redfern 1995). This might be a beneficial suppressive effect on estrogen-induced endometrial proliferation. RA can also effectively suppress the estrogen-stimulated proliferation of breast cancer cells and in several endometrial carcinoma lines (Carter et al. 1996, Toma et al. 1997). Targeting physiological RA accumulation in the endometrium by estradiol is a potential suppressor mechanism to prevent malignant transformation of hyperplastic endometrial cells during the ovarian cycle and gestation. In the case of vitamin A deficiency, uterine epithelium forms regions of 
keratinized squamous metaplasia, indicating that RA is needed to maintain simple columnar uterine epithelium (Ponnamperuma et al. 1999).

\section{Gap junction intercellular communications}

Decidualized stromal cells not only acquire epithelioid structure and function, accumulating glycogen, lipids and subcellular organelles (Lawn et al. 1971) but also express interdigitating lamellar processes within clustered microdomains called gap junctions. These gap junctions act as membranous channels for the direct exchange of small molecules (e.g., second messengers) among adjacent cells or between these cells and their extracellular environments (Yamasaki et al. 1999). Gap junction intercellular communications (GJIC) are critical to the success of decidualization because their blockade suppresses the proliferation and differentiation of uterine stromal cells (Yu et al. 2011, Diao et al. 2013, Yu et al. 2014a, Winterhager \& Kidder 2015). Connexin (CX) proteins are the major components of gap junctions, and CX43 (also known as GJA1) is the predominant CX protein in endometrial stromal cells (Jahn et al. 1995, Winterhager et al. 2009) and undergoes a variety of changes during the ovarian cycle (Mantena et al. 2006). The attenuation of CX43 expression disrupts GJIC between neighboring cells and impedes the differentiation of stromal cells in human and mouse endometrium (Laws et al. 2008, Yu et al. 2011). Endometrial CX43 may be regulated by hormonal changes, and the progesterone and estrogen levels in serum are reported to determine the expression levels of CX43 in the endometrium (Yu et al. 2014b, Winterhager \& Kidder 2015). RA and other retinoids enhance GJIC and CX43 expression levels in numerous cell types, certain human cancer cell types, mouse fibroblasts and rat liver cells, through transcriptional and translational mechanisms (Stahl \& Sies 1998, Carystinos et al. 2001). When treated with RA, CX43 expression in human endometrial stromal cells shows a dose-dependent increase at the mRNA and protein levels (Tanmahasamut \& Sidell 2005) (Table 2). Concomitant with the increase in CX43 expression, stromal cells treated with RA exhibit a 2.5-fold enhancement in their GJIC as assessed by dye transfer experiments (Tanmahasamut \& Sidell 2005). The ability of endometrial stromal cells to serve as an RA-responsive target is supported by the presence of RA nuclear receptors (i.e., RARs and RXRs) in these cells (Prentice 1992, Comptour et al. 2016). In addition to its expression level, the phosphorylation status of CX43 influences GJIC, including gap junction assembly and channel gating (Solan \& Lampe 2009). In endometrial tissue, phosphorylation of CX43 mostly impairs GJIC (Tanmahasamut \& Sidell 2005, Wu et al. 2013). Phosphorylation of CX43 is mediated by two serine/threonine protein kinase families, protein kinase C (PKC) (Oh et al. 1991) and MAPK (Warn-Cramer et al. 1996). RA induced the CX43 de-phosphorylation at serine 262 in human endometrial stromal cells (Tanmahasamut \& Sidell 2005, Wu et al. 2013). RA antagonized the effects of 12-O-tetradecanoylphorbol-13-acetate (a PKC activator) and inhibited PKC activity in numerous cell systems (Cope 1986, Verma 1988, Nakagawa et al. 2003), although the activation of PKC activity by RA has also been reported (Kambhampati et al. 2003). Inhibition of MAPK activity by RA was previously reported (Nakagawa et al. 2003). The signaling pathway(s) involved in the CX43-dephosphorylating effects of RA remains to be elucidated, but protein phosphatase 2 has been implicated (Wu et al. 2013). Overall, these data support that retinoid signaling can enhance GJIC among endometrial stromal cells (Fig. 3).

\section{Endometrial neovascularization}

Increased vascular permeability and angiogenesis are vital to the successful stromal decidualization, embryo

Table 2 Effect of RA on the production of factors in the endometrial cells.

\begin{tabular}{|c|c|c|c|}
\hline Factors & Regulation & Cell type & Species \\
\hline CX43 & $\uparrow$ & Stromal cells & Human \\
\hline VEGF & $\uparrow$ & Stromal cells & Human, mouse \\
\hline PRL & $\downarrow$ & Stromal cells & Human \\
\hline IGFBP1 & $\downarrow$ & Stromal cells & Human \\
\hline HSD11B1 & $\downarrow$ & Stromal cells & Human \\
\hline Fibronectin & $\uparrow$ & Stromal cells & Human \\
\hline LIF & $\downarrow$ & Epithelial cells & Mouse \\
\hline HB-EGF1 & $\downarrow$ & Epithelial cells & Mouse \\
\hline HSD17B2 & $\uparrow$ & Epithelial cells & Human \\
\hline
\end{tabular}

\section{References}

Tanmahasamut \& Sidell (2005), Wu et al. (2013)

Matsumoto \& Sato (2006), Sidell et al. (2010)

Brar et al. (1996), Ozaki et al. (2017)

Brar et al. (1996), Ozaki et al. (2017)

Ozaki et al. (2017)

Brar et al. (1996)

Ma et al. (2012)

Ma et al. (2012)

Cheng et al. (2008), Yamagata et al. (2015),

Pavone et al. (2017)

$\uparrow$, Upregulation; $\downarrow$, Downregulation. 
implantation and placentation (Dey et al. 2004, Matsumoto \& Sato 2006, Wang \& Dey 2006, Matsumoto et al. 2007). VEGF, originally reported as a vascular permeability factor, is also a potent mitogen for endothelial cells and a key regulatory growth factor for vasculogenesis or angiogenesis (Ferrara et al. 1997). In human endometrial stromal cells, RA can combine with transcriptional activators of VEGF to stimulate the expression and secretion of VEGF through a translational mechanism mediated by reactive oxygen species (ROS; Sidell et al. 2010) (Table 2). In addition, GJIC plays a key role in endometrial neovascularization. The conditional deletion of CX43 genes in stromal cells and the consequent disruption of GJIC result in the reduction of VEGF production and striking impairment in the development of new blood vessels within stromal compartments (Laws et al. 2008, Yu et al. 2011). Notably, CX43 overexpression promotes VEGF secretion (Yu et al. 2016). As discussed earlier, retinoid signaling can enhance GJIC among endometrial stromal cells by stimulating CX43 expression and dephosphorylation. Thus, retinoid signaling might promote neovascularization by enhancing stromal CX43 expression and GJIC. Evidence showed that COX-2-derived prostaglandins participate in uterine angiogenesis during implantation and decidualization (Matsumoto et al. 2002). In Cox-2 KO mice, failure of implantation and decidualization are primarily due to defects in VEGF signaling. cPGI (an analog of $\mathrm{PGI}_{2}$ ) together with 9cRA improves poor implantation in Cox-2(-/-) mice. Moreover, the administration of cPGI and 9cRA restore the expression of VEGF and angiogenesis (Matsumoto \& Sato 2006). In addition, Saito et al. (2007) examined RA effects on in vitro capillary-like tube formation using human umbilical vein endothelial cells and demonstrated that RA as well as RAR agonist Am80 significantly induced capillary-like tube formation. The RA-induced tube formation was inhibited by RAR antagonist. Meanwhile, the RA-induced tube formation was completely abolished by coincubation with VEGF antibody or with VEGF receptor (VEGFR)-2 antibody, but not VEGFR-1 antibody (Saito et al. 2007). These data provide evidence that although ovarian steroid hormones primarily influence uterine vascular permeability and angiogenesis during the preimplantation period, RA-RAR signaling participates by regulating VEGF production (Fig. 3).

\section{Stromal decidualization}

Stromal decidualization denotes the transformation of mesenchymal stromal cells into specialized decidual cells, which acquire epithelioid structure and function, accumulating glycogen, lipids and subcellular organelles (Lawn et al. 1971) in part through a process of mesenchymal-epithelial transformation ( $\mathrm{Yu}$ et al. 2016). Decidual cells provide the nutritive and immuneprivileged matrix that is required for blastocyst implantation and placental formation in mouse and human uteri (Zhang et al. 2013, Gellersen \& Brosens 2014). Perturbed or inadequate decidualization leads to embryo miscarriage and early pregnancy failure (Kommagani et al. 2013). Accompanied by typical morphological changes, differentiating stromal cells express biochemical decidual markers, such as prolactin (PRL), insulin-like growth factor-binding protein-1 (IGFBP1) (Irwin et al. 1994, Brar et al. 1997) and 11ß-hydroxysteroid dehydrogenase type 1 (11ßHSD1) (Brosens et al. 1999, Kuroda et al. 2013). Data from Ozaki et al. (2017) showed that RARs, as well as CRABP2 and FABP5, which are responsible for binding and delivering RA to nuclear receptors RARs and $\operatorname{PPAR} \beta / \delta$ respectively, decreased in decidualizing human endometrial stromal cells despite an increase in $\operatorname{PPAR} \beta / \delta$. Besides, decidualization was also associated with increased expression of CYP25A1 (Table 3). In addition, exposure of differentiating stromal cells to $10 \mathrm{nM}$ RA or retinal prevents the inhibition of the RAR pathway and perturbs expression of PRL, IGFBP1 and 11ßHSD1 (Ozaki et al. 2017). Brar et al. (1996) consistently demonstrated that RA treatment suppressed PRL and IGFBP1 production and promoted maintenance of fibronectin, an indicator of the undifferentiated stromal phenotype (Yu et al. 2016) (Table 2). Though PPAR $\beta / \delta$ and RXRs are highly expressed at implantation sites in human and rat endometrium (Fukunaka et al. 2001, Ding et al. 2003) and endometrial stromal cells can synthesize RA from retinol during decidualization and blastocyst implantation (Ulven et al. 2000, Deng et al. 2003), no evidence exists that RA, even at low concentrations, promotes stromal decidualization, at least not when assessed by the induction of responsive

Table 3 Upregulated and downregulated genes involved in retinoid metabolism and signaling in decidualizing endometrial stromal cells.

\begin{tabular}{|c|c|c|c|}
\hline Genes & $\begin{array}{l}\text { Upregulation or } \\
\text { downregulation }\end{array}$ & Species & References \\
\hline RBP4 & $\uparrow$ & Human & $\begin{array}{l}\text { Ozaki et al. (2017), } \\
\text { Pavone et al. (2017) }\end{array}$ \\
\hline CYP26A1 & $\uparrow$ & Human & Ozaki et al. (2017) \\
\hline$C R A B P 2$ & $\downarrow$ & Human & $\begin{array}{l}\text { Ozaki et al. (2017), } \\
\text { Pavone et al. (2017) }\end{array}$ \\
\hline$F A B P 5$ & $\downarrow$ & Human & Ozaki et al. (2017) \\
\hline$R A R \alpha$ & $\downarrow$ & Human & Ozaki et al. (2017) \\
\hline$P P A R \beta / \delta$ & $\uparrow$ & Human & Ozaki et al. (2017) \\
\hline
\end{tabular}

$\uparrow$, Upregulation; $\downarrow$, Downregulation; $\mathrm{E}_{2}$, estradiol; $\mathrm{P}_{4,}$ progesterone. 
decidual markers (PRL, IGFBP1 and HSD11B1). At high concentrations, RA decreases cell viability and exhibits toxic effects (Ozaki et al. 2017). These data suggested that RA signaling is attenuated upon decidualization, and RA treatment suppresses the decidualization and contributes to the maintenance of stromal cells in an undecidualized state. Furthermore, RA was suggested to prevent the increase in intracellular cAMP accumulation in stromal cells that occurs during the induction of decidualization in vitro with progesterone and estradiol (Brar et al. 1996). Meanwhile, the activation of the cAMP signal pathway is essential and sufficient to induce PRL production in endometrial stromal cells (Tang et al. 1993, Gellersen et al. 1994), and inhibition of PRL production by RA cannot be restored by cAMP treatment (Brar et al. 1996). The inhibition of intracellular cAMP production by RA is a plausible mechanism by which RA suppresses stromal decidualization. On the other hand, endogenous RA biosynthesis from retinol is increased 1.4-fold in endometrial stromal cells subjected to in vitro decidualization compared to control cells (Sidell et al. 2010). Thus, more precise dose-response relationships should be established to fully understand the possible differential effects of RA signaling via the opposing CRABP2-RAR vs FABP5-PPAR $\beta$ pathways.

\section{Retinoid signaling in blastocyst implantation}

In humans and rodents, implantation occurs via successive blastocyst apposition, attachment, and adhesion to the receptive luminal epithelium, followed by the penetration and invasion of trophectoderm into the decidualized stroma (Dey et al. 2004). Successful implantation requires not only a receptive endometrium but also a preimplantation blastocyst temporally competent to engage in precise crosstalk with the maternal endometrial signals. Recent evidence suggested that two separate uterine signals during blastocyst implantation. One signal primes the trophectoderm for attachment to the luminal epithelium, and the other results in the uptake of amino acids by the blastocyst, the motility of which is initiated for invasion (Gonzalez 2012). Signaling of endometrial receptivity to blastocyst attachment involves the actions of ovarian steroid hormones on the luminal epithelia and paracrine factors expressed by different endometrial cell types (Cha et al. 2012, Zhang et al. 2013).

Rodent studies demonstrated that the tight regulation of retinoid pathways play crucial roles in maintaining uterine receptivity and blastocyst implantation (Osteen et al. 2003, Han et al. 2010). In mice, the uterus becomes receptive to blastocyst implantation by the afternoon of gestational day 4 but is refractory by the afternoon of day 5 (Zhang et al. 2013). No Cyp26a1 mRNA was found in preimplantation endometrium, while its expression was specifically induced between 3.5 and 4.5 gestational days, i.e., the implantation period, was localized in luminal epithelia (Vermot et al. 2000, Han et al. 2010). The specific spatiotemporal expression pattern of Cyp26a1 in preimplantation endometrium suggests that it is involved in blastocyst attachment and/or invasion to the endometrium but not in the initial preparations of the endometrium. This hypothesis was supported by data in which the number of implantation sites was significantly reduced when Cyp26a1-specific antisense oligos or antiCYP26A1 antibodies were injected into the uterus on day 3 of pregnancy (Han et al. 2010). As described previously, the RA pathway is inhibited during the late secretory phase by endogenous expression of Cyp26a1. RA can inhibit matrix metalloproteases (Bruner-Tran et al. 2002, Osteen et al. 2003), thus, CYP26A1-mediated degradation of RA may facilitate blastocyst implantation (Osteen et al. 2003).

Pharmacological concentrations of RA are embryotoxic at the early postimplantation stage of development (Huang et al. 2001). This observation, along with the well-characterized functions played by CXs in embryonic implantation and development, suggests a possible link between known teratogenic effects of RA (Ross et al. 2000) and the possibility that RA at such concentrations may reduce the effective trophoblast invasive capacity through increased GJIC because CX43 expression and GJIC are dramatically reduced during the implantation window (Granot et al. 2000) potentially facilitating trophectoderm invasion into the endometrial stroma.

Other studies established the importance of endometrial gland secretions, such as leukemia inhibitory factor (LIF), for endometrial receptivity and blastocyst implantation. LIF binds to its receptor LIFR present in luminal epithelia and activates downstream signaling via STAT3 (Niwa et al. 1998). Consequently, LIF induces the expression of luminal epithelia-enriched genes, including HB-EGF1, IGFBP3 and IRG, which are associated with uterine receptivity (Kimber 2005). Lif KO mice are infertile because of the failure of blastocyst attachment to the uterine luminal epithelium. Excess RA $(10 \mu \mathrm{M})$ can significantly inhibit the expression of the Lif, Hb-egf and Csf1 in endometrial epithelial cells isolated on day 4.5 of pregnancy (Ma et al. 2012) (Table 2).

These data suggest that successful implantation during late secretory phase requires lower RA levels in the 
luminal epithelia than what occurs in the proliferative phase, and excess RA might negatively affect stromal decidualization, endometrial receptivity and blastocyst implantation. CYP26A1-mediated degradation of RA is a hallmark of the implantation phase.

Collectively, the endometrial retinoid pathway is distinctly regulated by synthesis catalyzed by ALDHs and catabolism catalyzed by CYP26A1 at different phases and in different compartments of the endometrium, which are mainly controlled by estradiol and progesterone. The retinoid pathwayplayscrucialrolesinendometrialepithelial differentiation and proliferation, neovascularization and GJIC and negatively regulates stromal decidualization and blastocyst implantation (Fig. 3).

\section{Retinoid pathway and endometriosis}

Endometriosis is a nonmalignant, but potentially metastatic, gynecological condition, which is estrogen dependent and defined by the presence of hormonally responsive, ectopic implants of endometrial mucosa dispersed in extrauterine locations (Giudice \& Kao 2004, Kennedy et al. 2005). Approximately $10 \%$ of all women and up to $30 \%-50 \%$ of symptomatic premenopausal women are affected and commonly suffer pelvic pain and/or infertility (Nnoaham et al. 2011, Stilley et al. 2012). Classical and neoclassical concepts of endometriosis etiology were reviewed comprehensively elsewhere (Bulun 2009, Taylor 2010, Burney \& Giudice 2012, Bulun et al. 2015, Taylor et al. 2015) and will not be reiterated thoroughly in this review. Although the theories of endometriosis histogenesis remain controversial, recent findings suggest that defective epigenetic landscape possibly associated with deficient differentiation of endometrial tissue stem cells is a central mechanism responsible for the cellular origins of endometriosis (Bulun et al. 2015). Meanwhile, retinoid pathway is fundamentally flawed in endometriotic tissues and even systemically in women with endometriosis (Pavone et al. 2010, 2011, 2017, Pierzchalski et al. 2014, Taylor et al. 2015).

Studies from the group of Bulun showed altered expression of several genes involved in retinol uptake, metabolism and action in cells from patients with endometriosis (Pavone et al. 2010, 2011, 2017). Endometriotic stromal cells overall had decreased CRABP2 and CRBP1 expression and increased CYP26B1 expression (Table 4), the latter resulting in the elimination of RA from cells. These results are consistent with decreased retinoid uptake, metabolism and action within endometriotic lesions (Pavone et al. 2011). ALDH1A2 expression levels were significantly reduced in endometriotic tissue and stromal cells (Table 4), resulting in reduced RA levels. Pierzchalski et al. (2014) directly quantified RA levels and biosynthesis from retinol in endometrial stromal cells, which were derived from corresponding eutopic and ectopic biopsies; retinol uptake and RA production predominantly occur in these stromal cells (Vermot et al. 2000, Pavone et al. 2011, Yamagata et al. 2014) (Fig. 1). The studies confirmed impaired RA biosynthesis in endometriotic implants. A major defect was the reduced expression of CRBP1, a retinol carrier protein serving as the preferred substrate for retinol dehydrogenase enzymes and the rate-limiting factor in RA biosynthesis (Napoli 2012). Moreover, STRA6, which mediates retinol uptake, showed an abnormally low expression and high levels of DNA methylation in endometriotic stromal cells (Pavone et al. 2011, Yamagata et al. 2015) (Table 4). Thus, reduced STRA6, CRBP1 and ALDH1A2 expression levels result in a significantly less efficient conversion of retinol to RA in stromal cells. In addition, $R A R \alpha$ expression levels are strikingly low in tissues and stromal cells of endometriosis (Pavone et al. 2011) (Table 4). Transcriptional activation via the RA-CRABP2-RAR pathway can trigger cell cycle arrest (Donato et al. 2007) and apoptosis (Altucci et al. 2001, Kitareewan et al. 2002, Donato et al. 2005) and frequently leads to the inhibition of cell proliferation. Thus, reduced RA-CRABP2-RAR signaling can cause endometriotic cells to escape apoptosis and contribute to the survival of ectopic cells (Nasu et al. 2009, Pavone et al. 2010). These studies suggested that flaws in RA production and degradation might play a role in the pathogenesis of endometriosis.

Table 4 Changes in genes involved in retinoid uptake, metabolism and signaling in endometriosis.

\begin{tabular}{|c|c|c|c|}
\hline Genes & Changes & Cell type & References \\
\hline CRBP1 & $\downarrow$ & Stromal cells & $\begin{array}{l}\text { Pavone et al. (2011, } \\
\text { 2017) }\end{array}$ \\
\hline$C R A B P 2$ & $\downarrow$ & Stromal cells & $\begin{array}{l}\text { Pavone et al. (2010, } \\
\text { 2011, 2017) }\end{array}$ \\
\hline$A L D H 1 A 2$ & $\downarrow$ & Stromal cells & Pavone et al. (2011) \\
\hline STRA6 & $\downarrow$ & Stromal cells & $\begin{array}{l}\text { Pavone et al. (2010, } \\
\text { 2011), Yamagata et al. } \\
\text { (2015) }\end{array}$ \\
\hline$R A R \alpha$ & $\downarrow$ & Stromal cells & Pavone et al. (2011) \\
\hline$R X R \alpha$ & $\downarrow$ & Stromal cells & Pavone et al. (2011) \\
\hline CYP26B1 & $\uparrow$ & Stromal cells & $\begin{array}{l}\text { Pavone et al. (2011, } \\
\text { 2017) }\end{array}$ \\
\hline
\end{tabular}

$\downarrow$, reduced; $\uparrow$, increased 
Estrogen plays a critical role in the establishment and maintenance of endometriosis (Osteen et al. 2005, Bulun 2009, Bulun etal. 2015). 17 $\beta$-hydroxysteroid dehydrogenase type 2 (HSD17B2) catalyzes the conversion of estradiol to estrone, a much less biologically potent estrogen, and plays a crucial role in local estradiol inactivation in the endometrium (Cheng et al. 2007). HSD17B2 is present in normal endometrial glandular cells but is lacking in the endometrium of women with endometriosis (Stewart 1994, Giudice et al. 2002). Pavone et al. (2017) incubated epithelial cells with human serum RBP4 for $48 \mathrm{~h}$ and found that HSD17B2 expression was significantly increased in a dose-dependent manner. In serum, retinol is bound by RBP4 in the form of retinol-RBP4 complex (holo-RBP4),

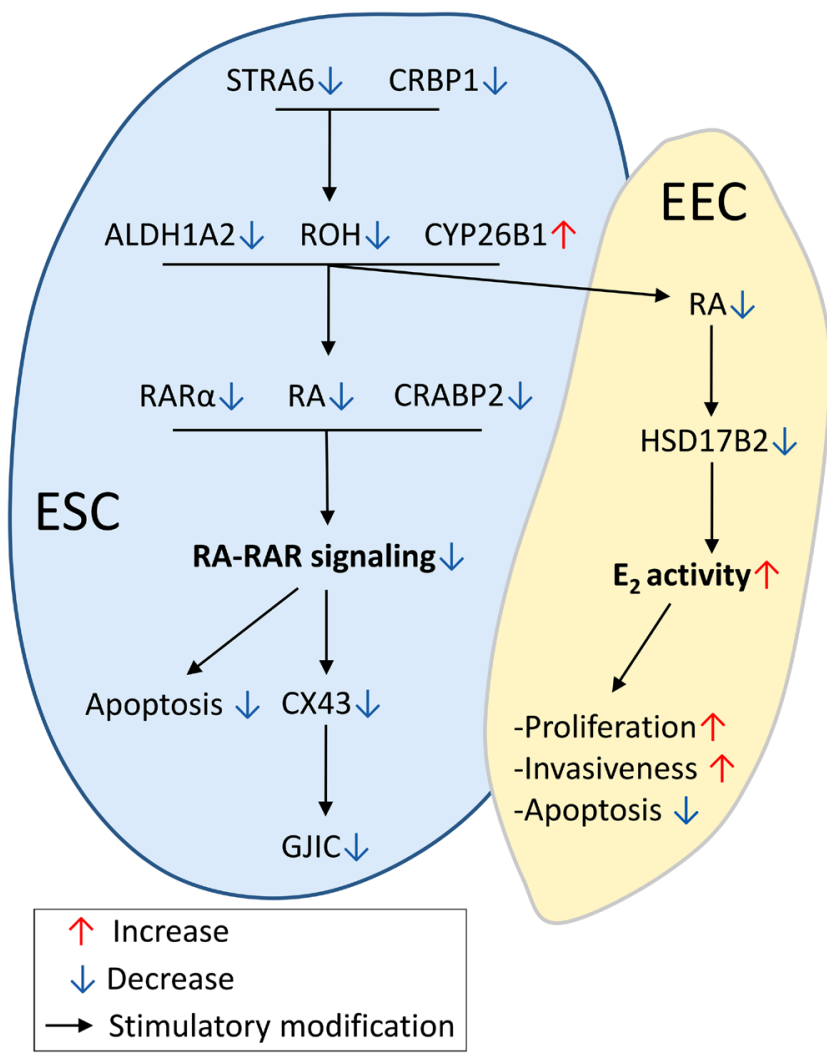

Figure 4

Schematic representation of aberrant retinoid signaling in endometriosis. In stromal cells of endometriosis, reduced STRA6, CRBP1 and ALDH1A2 expression levels result in a significantly less efficient conversion of retinol to RA. Meanwhile, increased CYP26A1 expression promotes RA degradation. Thus, decreased RA levels along with reduced RAR $\alpha$ and CRABP2 expression result in a reduced RA-RAR signaling, which results in reduced Cx43 expression and GJIC in stromal cells. Meanwhile, reduced RA levels result in lower HSD17B2 production and high local concentrations of estradiol $\left(E_{2}\right)$ in epithelial cells of endometriosis. The reduced RA signaling and increased local $E_{2}$ activity could enhance cell proliferation, invasiveness and impede apoptosis in endometriosis. A full colour version of this figure is available at https://doi.org/10.1530/ JOE-17-0544. which then binds to transthyretin (TTR) and forms a ternary complex (D'Ambrosio et al. 2011). Binding of holo-RBP4 to TTR prevents the loss of the RBP4 from the circulation by filtration via the renal glomeruli, as apoRBP4 cannot be bound by TTR and is lost in the urine. Since the human serum RBP4 used in the study of Pavone et al. (2017) may contain significant amounts of holoRBP4, the increased HSD17B2 expression might be caused by retinol from holo-RBP4. This hypothesis was supported by another study which demonstrated that RA stimulates the assembly of a multimeric complex composed of RAR $\alpha /$ RXR $\alpha$ tethered to transcription factors SP1 and SP3 on the $H S D 17 B 2$ promoter where it induces HSD17B2. The RA antagonist ANG abolishes RA-induced HSD17B2 expression in endometrial cells (Cheng et al. 2008, Yamagata et al. 2015). Thus, RA appears to be one of the critical paracrine factors that stimulate the production of HSD17B2 in neighboring epithelial cells and an important mechanism for local estradiol inactivation in the endometrium (Table 2). As previously mentioned, as the RA pathway is fundamentally flawed in endometriotic tissues (Pavone et al. 2010), this provides a plausible explanation for the aberrant HSD17B2 expression and the high local estradiol concentrations in endometriosis (Fig. 4).

As previously mentioned, CX43 is predominantly expressed in endometrial stromal cells (Jahn et al. 1995, Winterhager et al. 2009) and necessary for GJIC that allow the stroma to serve as an organized tissue. Regidor et al. (1997) showed that CX43 levels were reduced in human endometriosis lesions and this finding was confirmed by Yu et al. (2014b). They reported nearly exclusive CX43 immunostaining in the stromal compartment of normal biopsies, with reduced immunostaining and redistribution to scattered epithelia in the eutopic endometria of women with endometriosis. Moreover, stromal cells isolated from cases of endometriosis exhibited a reduction of $\sim 45 \%$ in GJIC, confirmed at the levels of CX43 mRNA and protein expression and also functionally by lower Lucifer Yellow diffusion (Yu et al. 2014b). As previously mentioned, RA can stimulate CX43 expression and GJIC in stromal cells (Tanmahasamut \& Sidell 2005, Wu et al. 2013). Thus, flawed retinoid action might cause decreased CX43 expression and GJIC, reducing decidualization capacity of stromal cells in endometriosis, which could contribute to the development or progression of endometriosis lesions and to the subfertile uterine phenotype associated with the syndrome.

TGF- $\beta 1$, a member of transforming growth factor- $\beta$ (TGF- $\beta$ ) superfamily, has been supposed to play an extensive role in the onset and development of endometriosis, such 


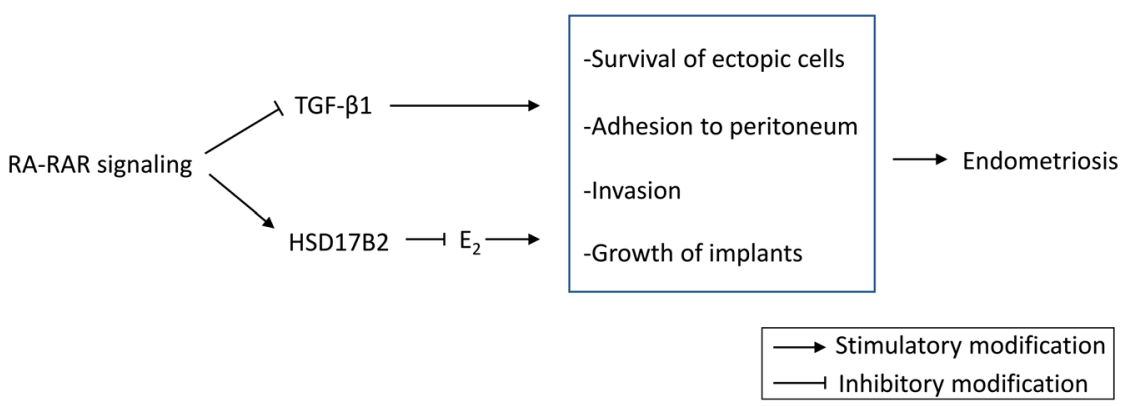

\section{Figure 5}

Potential therapeutic mechanism of RA for endometriosis. Activation of the RA-RAR pathway can promote HSD17B2 production, which can stimulate the catabolism of $E_{2}$ and inhibit TGF- $\beta 1$ production. These actions of the RA-RAR pathway imply its potential to suppress the development of endometriosis. A full colour version of this figure is available at https://doi.org/10.1530/ JOE-17-0544. as preventing apoptosis during transit to the peritoneal cavity, promoting adhesion to peritoneum and invasion of endometriosis cells (Omwandho et al. 2010). With the exception of one study (Hao et al. 2000), two other studies reported that subjects with endometriosis exhibit higher levels of TGF- $\beta 1$ in peritoneal fluid (Oosterlynck et al. 1994, Ku“pker et al. 1998). Interestingly, it was reported that RA could inhibit the TGF- $\beta 1$ signaling pathway in the endometrial cells and many other cell types (Frenz \& Liu 2000, Delgadillo et al. 2014, Hu et al. 2016). Althoughfurther studies are needed, it can be speculated that RA might suppress the development of endometriosis implants partly through repressing the TGF- $\beta 1$ signaling pathway (Fig. 5).

These data suggest two possible scenarios to consider the theories of the histogenesis of endometriosis associated with the aberrant retinoid pathway in ectopically growing endometrial cells. On the one hand, defects in RA signaling can result in high local concentrations of estradiol in endometriosis lesions due to deficient oxidation and inactivation of estradiol. On the other hand, reduced RA signaling, along with increased estradiol effects, could enhance cell proliferation and invasiveness and impede apoptosis in endometriosis (Fig. 4). With respect to eutopic endometrial function in endometriosis, impaired RA signaling can be an attributed to dysfunctional stromal differentiation, leading to the reduced capacity for decidualization reported in these cases (Klemmt et al. 2006, Aghajanova et al. 2009, Lessey et al. 2013).

In conclusion, the precisely controlled retinoid signaling may play a critical role in a number of critical endometrial physiological events. In addition, the altered RA pathway may be a leading cause for the histogenesis of endometriosis.

\section{Perspectives for future studies}

RBP4, acting as the primary systemic and intercellular transporter of retinol, plays a key role in cellular retinol influx, efflux and exchange (Kawaguchi et al. 2015).
Pavone et al. (2017) observed that RBP4 secretion increases during the decidualization of human endometrial stromal cells. Immunoreactivity for RBP4 is consistently higher near the embryo implantation site compared with non-implantation sites in the baboon endometrium (Fazleabas et al. 1994). These data suggest a potential role of RBP4 production and secretion in decidualization and/or implantation, but still require further investigation. Of great interest is that complete deletion of Aldh genes in mice results in prenatal lethality, precluding investigation of their roles in postnatal organogenesis. The use of tissue-selective and conditional gene targeting approaches is necessary to better understand the role of these enzymes during the ovarian cycle and gestation. As previously mentioned, excess RA concentration is harmful to decidualization and implantation. Thus, actual retinoid concentrations in the endometrium, as have been performed in some limited studies (Pierzchalski et al. 2014), should be measured in future studies.

Accumulating evidence supports that treatment modalities that target the retinoid pathway may have therapeutic utility (Sokalska et al. 2013). RA treatment reduced cytokine concentrations and the number and size of lesions (Wieser et al. 2012). Thus, RA has the potential to suppress the development of endometriotic implants and agents that target the RA-shuttling system may be useful therapeutic targets in the future, bypassing the toxicity and teratogenicity encountered with RA analogs (Fig. 5). We propose that adjuvant or alternative medical therapies should be developed on the basis of these concepts. Their pharmacological actions and anticipated low side-effect profiles are predicted to be able to provide women with endometriosis with more treatment options for the long-term management of chronic and debilitating gynecologic diseases.

\section{Declaration of interest}

The authors declare that there is no conflict of interest that could be perceived as prejudicing the impartiality of this review. 
Funding

This work was supported by the National Natural Science Foundation of China (31372308 to X Z, 31772596 to X Z, 31672417 to C L and 31301969 to $L C$ ) and by the Eunice Kennedy Shriver National Institute of Child Health and Human Development (USA) as part of the Cooperative Research Partnerships to Promote Workforce Diversity in the Reproductive Sciences (U01 HD66439 to R N T).

\section{References}

Aghajanova L, Hamilton A, Kwintkiewicz J, Vo KC \& Giudice LC 2009 Steroidogenic enzyme and key decidualization marker dysregulation in endometrial stromal cells from women with versus without endometriosis. Biology of Reproduction 80 105-114. (https://doi. org/10.1095/biolreprod.108.070300)

Al Tanoury Z, Piskunov A \& Rochette-Egly C 2013 Vitamin A and retinoid signaling: genomic and nongenomic effects. Journal of Lipid Research 54 1761-1775. (https://doi.org/10.1194/jlr.R030833)

Altucci L, Rossin A, Raffelsberger W, Reitmair A, Chomienne C \& Gronemeyer H 2001 Retinoic acid-induced apoptosis in leukemia cells is mediated by paracrine action of tumor-selective death ligand TRAIL. Nature Medicine 7 680-686. (https://doi.org/10.1038/89050)

Benson GV, Lim H, Paria BC, Satokata I, Dey SK \& Maas RL 1996 Mechanisms of reduced fertility in Hoxa-10 mutant mice: uterine homeosis and loss of maternal Hoxa-10 expression. Development 122 2687-2696.

Bo WJ \& Smith MS 1966 The effect of retinol and retinoic acid on the morphology of the rat uterus. Anatomical Record 156 5-9. (https://doi. org/10.1002/ar.1091560103)

Boehm N, Chateau D \& Rochette-Egly C 1997 Retinoid receptors in rat vaginal and uterine epithelia: changes with ovarian steroids. Molecular and Cellular Endocrinology 132 101-108. (https://doi.org/10.1016/ S0303-7207(97)00126-3)

Boettger-Tong HL\& Stancel GM 1995 Retinoic acid inhibits estrogeninduced uterine stromal and myometrial cell proliferation. Endocrinology 136 2975-2983. (https://doi.org/10.1210/ endo.136.7.7789323)

Brar AK, Kessler CA, Meyer AJ, Cedars MI \& Jikihara H 1996 Retinoic acid suppresses in-vitro decidualization of human endometrial stromal cells. Molecular Human Reproduction 2 185-193. (https://doi. org/10.1093/molehr/2.3.185)

Brar AK, Frank GR, Kessler CA, Cedars MI \& Handwerger S 1997 Progesterone-dependent decidualization of the human endometrium is mediated by cAMP. Endocrine 6 301-307. (https://doi.org/10.1007/ BF02820507)

Brosens JJ, Hayashi N \& White JO 1999 Progesterone receptor regulates decidual prolactin expression in differentiating human endometrial stromal cells. Endocrinology 140 4809-4820. (https://doi.org/10.1210/ endo.140.10.7070)

Bruner-Tran KL, Eisenberg E, Yeaman GR, Anderson TA, McBean J \& Osteen KG 2002 Steroid and cytokine regulation of matrix metalloproteinase expression in endometriosis and the establishment of experimental endometriosis in nude mice. Journal of Clinical Endocrinology and Metabolism 87 4782-4791. (https://doi.org/10.1210/ jc.2002-020418)

Bryant SL, Francis JC, Lokody IB, Wang H, Risbridger GP, Loveland KL \& Swain A 2014 Sex specific retinoic acid signaling is required for the initiation of urogenital sinus bud development. Developmental Biology 395 209-217. (https://doi.org/10.1016/j.ydbio.2014.09.016)

Bucco RA, Zheng WL, Davis JT, Sierra-Rivera E, Osteen KG, Chaudhary AK \& Ong DE 1997 Cellular retinoic acid-binding protein(II) presence in rat uterine epithelial cells correlates with their synthesis of retinoic acid. Biochemistry 36 4009-4014. (https://doi.org/10.1021/bi962094o)
Bulun SE 2009 Endometriosis. New England Journal of Medicine 360 268-279. (https://doi.org/10.1056/NEJMra0804690)

Bulun SE, Monsivais D, Kakinuma T, Furukawa Y, Bernardi L, Pavone ME \& Dyson M 2015 Molecular biology of endometriosis: from aromatase to genomic abnormalities. Seminars in Reproductive Medicine $\mathbf{3 3}$ 220-224. (https://doi.org/10.1055/s-0035-1554053)

Burney RO \& Giudice LC 2012 Pathogenesis and pathophysiology of endometriosis. Fertility and Sterility 98 511-519. (https://doi. org/10.1016/j.fertnstert.2012.06.029)

Carter CA, Pogribny M, Davidson A, Jackson CD, McGarrity LJ \& Morris SM 1996 Effects of retinoic acid on cell differentiation and reversion toward normal in human endometrial adenocarcinoma (RL95-2) cells. Anticancer Research 16 17-24.

Carystinos GD, Bier A \& Batist G 2001 The role of connexin-mediated cell-cell communication in breast cancer metastasis. Journal of Mammary Gland Biology and Neoplasia 6 431-440. (https://doi. org/10.1023/A:1014787014851)

Cha J, Sun X \& Dey SK 2012 Mechanisms of implantation: strategies for successful pregnancy. Nature Medicine 18 1754-1767. (https://doi. org/10.1038/nm.3012)

Chambon P 2005 The nuclear receptor superfamily: a personal retrospect on the first two decades. Molecular Endocrinology 19 1418-1428. (https://doi.org/10.1210/me.2005-0125)

Chan CCW, Lao TT, Ho PC, Sung EOP \& Cheung ANY 2003 The effect of mifepristone on the expression of steroid hormone receptors in human decidua and placenta: a randomized placebo-controlled double-blind study. Journal of Clinical Endocrinology and Metabolism 88 5846-5850. (https://doi.org/10.1210/jc.2003-030958)

Cheng YH, Imir A, Fenkci V, Yilmaz MB \& Bulun SE 2007 Stromal cells of endometriosis fail to produce paracrine factors that induce epithelial 17ß-hydroxysteroid dehydrogenase type 2 gene and its transcriptional regulator Sp1: a mechanism for defective estradiol metabolism. American Journal of Obstetrics and Gynecology 196 391.e1-e7. (https://doi.org/10.1016/j.ajog.2006.12.014)

Cheng YH, Yin P, Xue Q, Yilmaz B, Dawson MI \& Bulun SE 2008 Retinoic acid (RA) regulates 17beta-hydroxysteroid dehydrogenase type 2 expression in endometrium: interaction of RA receptors with specificity protein (SP) 1/SP3 for estradiol metabolism. Journal of Clinical Endocrinology and Metabolism 93 1915-1923. (https://doi. org/10.1210/jc.2007-1536)

Chithalen JV, Luu L, Petkovich M \& Jones G 2002 HPLC-MS/MS analysis of the products generated from all-trans-retinoic acid using recombinant human CYP26A. Journal of Lipid Research 43 1133-1142. (https://doi.org/10.1194/jlr.M100343-JLR200)

Comptour A, Rouzaire M, Belville C, Bouvier D, Gallot D, Blanchon L \& Sapin V 2016 Nuclear retinoid receptors and pregnancy: placental transfer, functions, and pharmacological aspects. Cellular and Molecular Life Sciences 73 3823-3837. (https://doi.org/10.1007/s00018016-2332-9)

Conaway HH, Henning P \& Lerner UH 2013 Vitamin a metabolism, action, and role in skeletal homeostasis. Endocrine Reviews $\mathbf{3 4}$ 766-797. (https://doi.org/10.1210/er.2012-1071)

Cope FO 1986 The in vivo inhibition of mouse brain protein kinase-C by retinoic acid. Cancer Letters 30 275-288. (https://doi. org/10.1016/0304-3835(86)90052-2)

D'Ambrosio DN, Clugston RD \& Blaner WS 2011 Vitamin A metabolism: an update. Nutrients 3 63-103. (https://doi.org/10.3390/nu3010063)

Darwiche N, Celli G, Sly L, Lancillotti F \& De Luca LM 1993 Retinoid status controls the appearance of reserve cells and keratin expression in mouse cervical epithelium. Cancer Research 53 2287-2299.

Delacroix L, Moutier E, Altobelli G, Legras S, Poch O, Choukrallah MA, Bertin I, Jost B \& Davidson I 2010 Cell-specific interaction of retinoic acid receptors with target genes in mouse embryonic fibroblasts and embryonic stem cells. Cell and Molecular Biology 30 231-244. (https://doi.org/10.1128/MCB.00756-09)
C 2018 Society for Endocrinology Published by Bioscientifica Ltd. Printed in Great Britain 
Delgadillo D, Barbier O, Sierra G \& Reyes JL 2014 Retinoic acid improves recovery after nephrectomy and decreases renal TGF- $\beta 1$ expression. Gender-related effects. Fundamental and Clinical Pharmacology $\mathbf{2 8}$ 170-179. (https://doi.org/10.1111/fcp.12013)

Delva L, Bastie J, Rochette-Egly C, Kraiba R, Balitrand N, Despouy G, Chambon P \& Chomienne C 1999 Physical and functional interactions between cellular retinoic acid binding protein II and the retinoic acid-dependent nuclear complex. Molecular and Cellular Biology 19 7158-7167. (https://doi.org/10.1128/MCB.19.10.7158)

Deng L, Shipley GL, Loose-Mitchell DS, Stancel GM, Broaddus R, Pickar JH \& Davies PJ 2003 Coordinate regulation of the production and signaling of retinoic acid by estrogen in the human endometrium. Journal of Clinical Endocrinology and Metabolism $\mathbf{8 8}$ 2157-2163. (https://doi.org/10.1210/jc.2002-021844)

Dey SK, Lim H, Das SK, Reese J, Paria BC, Daikoku T \& Wang H 2004 Molecular cues to implantation. Endocrine Reviews 25 341-373. (https://doi.org/10.1210/er.2003-0020)

Diao H, Xiao S, Howerth EW, Zhao F, Li R, Ard MB \& Ye X 2013 Broad gap junction blocker carbenoxolone disrupts uterine preparation for embryo implantation in mice. Biology of Reproduction 8931. (https://doi.org/10.1095/biolreprod.113.110106)

Ding NZ, Ma XH, Diao HL, Xu LB \&Yang ZM 2003 Differential expression of peroxisome proliferator-activated receptor delta at implantation sites and in decidual cells of rat uterus. Reproduction 125 817-825. (https://doi.org/10.1530/rep.0.1250817)

Donato LJ \& Noy N 2005 Suppression of mammary carcinoma growth by retinoic acid: proapoptotic genes are targets for retinoic acid receptor and cellular retinoic acid-binding protein II signaling. Cancer Research 65 8193-8199. (https://doi.org/10.1158/0008-5472.CAN-05-1177)

Donato LJ, Suh JH \& Noy N 2007 Suppression of mammary carcinoma cell growth by retinoic acid: the cell cycle control gene Btg2 is a direct target for retinoic acid receptor signaling. Cancer Research 67 609-615. (https://doi.org/10.1158/0008-5472.CAN-06-0989)

Dong D, Ruuska S, Levinthal D \& Noy N 1999. Distinct roles for cellular retinoic acid-binding proteins I and II in regulating signaling by retinoic acid. Journal of Biological Chemistry 274 23695-23698. (https://doi.org/10.1074/jbc.274.34.23695)

Duester G 2000 Families of retinoid dehydrogenases regulating vitamin A function: production of visual pigment and retinoic acid. European Journal of Biochemistry 267 4315-4324. (https://doi.org/10.1046/ j.1432-1327.2000.01497.x)

Farjo KM, Moiseyev G, Nikolaeva O, Sandell LL, Trainor PA \& Ma JX 2011 RDH10 is the primary enzyme responsible for the first step of embryonic Vitamin A metabolism and retinoic acid synthesis. Developmental Biology 357 347-355. (https://doi.org/10.1016/j. ydbio.2011.07.011)

Fazleabas AT, Donnelly KM, Mavrogianis PA \& Verhage HG 1994 Retinol-binding protein in the baboon (Papio anubis) uterus: immunohistochemical characterization and gene expression. Biology of Reproduction 50 1207-1215. (https://doi.org/10.1095/ biolreprod50.6.1207)

Ferrara N \& Davis-Smyth T 1997 The biology of vascular endothelial growth factor. Endocrine Reviews 18 4-25. (https://doi.org/10.1210/ edrv.18.1.0287)

Filant J \& Spencer TE 2013 Endometrial glands are essential for blastocyst implantation and decidualization in the mouse uterus. Biology of Reproduction 88 93. (https://doi.org/10.1095/biolreprod.113.107631)

Frenz DA \& Liu W 2000 Treatment with all-trans-retinoic acid decreases levels of endogenous TGF- $\beta 1$ in the mesenchyme of the developing mouse inner ear. Teratology 61 297-304. (https://doi.org/10.1002/ (SICI)1096-9926(200004)61:4<297::AID-TERA9>3.0.CO;2-H)

Fritzsche B, Vermot J, Neumann U, Schmidt A, Schweigert FJ, Dollé P \& Rühl R 2007 Regulation of expression of the retinoic acid metabolizing enzyme CYP26A1 in uteri of ovariectomized mice after treatment with ovarian steroid hormones. Molecular Reproduction and Development 74 258-264. (https://doi.org/10.1002/mrd.20526)
Fukunaka K, Saito T, Wataba K, Ashihara K, Ito E \& Kudo R 2001 Changes in expression and subcellular localization of nuclear retinoic acid receptors in human endometrial epithelium during the menstrual cycle. Molecular Human Reproduction 7 437-446. (https://doi. org/10.1093/molehr/7.5.437)

Garry R, Hart R, Karthigasu KA \& Burke C 2010 Structural changes in endometrial basal glands during menstruation. BJOG 117 1175-1185. (https://doi.org/10.1111/j.1471-0528.2010.02630.x)

Gellersen B \& Brosens JJ 2014 Cyclic decidualization of the human endometrium in reproductive health and failure. Endocrine Reviews $\mathbf{3 5}$ 851-905. (https://doi.org/10.1210/er.2014-1045)

Gellersen B, Kempf R, Telgmann R \& DiMattia GE 1994 Nonpituitary human prolactin gene transcription is independent of Pit-1 and differentially controlled in lymphocytes and in endometrial stroma. Molecular Endocrinology 8 356-373. (https://doi.org/10.1210/ me.8.3.356)

Giudice LC \& Kao LC 2004 Endometriosis. Lancet 364 1789-1799. (https://doi.org/10.1016/S0140-6736(04)17403-5)

Giudice LC, Telles TL, Lobo S \& Kao L 2002 The molecular basis for implantation failure in endometriosis: on the road to discovery. Annals of the New York Academy of Sciences 955 252-264. (https://doi. org/10.1111/j.1749-6632.2002.tb02786.x)

Gonzalez IM, Martin PM, Burdsal C, Sloan JL, Mager S, Harris T \& Sutherland AE 2012 Leucine and arginine regulate trophoblast motility through mTOR-dependent and independent pathways in the preimplantation mouse embryo. Developmental Biology 361 286-300. (https://doi.org/10.1016/j.ydbio.2011.10.021)

Granot I, Dekel N, Bechor E, Segal I, Fieldust S \& Barash A 2000 Temporal analysis of connexin 43 protein and gene expression throughout the menstrual cycle in human endometrium. Fertility and Sterility $\mathbf{7 3}$ 381-386. (https://doi.org/10.1016/S0015-0282(99)00531-2)

Han BC, Xia HF, Sun J, Yang Y \& Peng JP 2010 Retinoic acid-metabolizing enzyme cytochrome P450 26a1 (cyp26a1) is essential for implantation: functional study of its role in early pregnancy. Journal of Cellular Physiology 223 471-479. (https://doi.org/10.1002/jcp.22056)

Hao M, Shi Y \& Dong M 2000 Measurements of interleukin-6, interleukin- 8 and transforming growth factor-beta1 levels in peritoneal fluid of patients with endometriosis. Zhonghua Fu Chan Ke Za Zhi 35 329-331.

Harrison EH 2005 Mechanisms of digestion and absorption of dietary vitamin A. Annual Review of Nutrition 25 87-103. (https://doi. org/10.1146/annurev.nutr.25.050304.092614)

Hu J, Gray CA \& Spencer TE 2004 Gene expression profiling of neonatal mouse uterine development. Biology of Reproduction 70 1870-1876. (https://doi.org/10.1095/biolreprod.103.026336)

Hu HY, Li HJ, He YL \& Wang X 2016 ATRA alleviated endometrial fibrosis in a rabbit intrauterine adhesions model through downregulation of the TGF- $\beta 1 /$ smad 4 signaling pathway. International Journal of Clinical and Experimental Pathology 9 6171-6178.

Huang F-J, Wu T-C \& Tsai M-Y 2001 Effect of retinoic acid on implantation and postimplantation development of mouse embryos in vitro. Human Reproduction 16 2171-2176. (https://doi.org/10.1093/ humrep/16.10.2171)

Huang CC, Orvis GD, Wang Y \& Behringer RR 2012 Stromal-to-epithelial transition during postpartum endometrial regeneration. PLOS ONE 7 e44285. (https://doi.org/10.1371/journal.pone.0044285)

Irwin JC, de las Fuentes L \& Giudice LC 1994 Growth factors and decidualization in vitro. Annals of the New York Academy of Sciences 734 7-18. (https://doi.org/10.1111/j.1749-6632.1994.tb21730.x)

Jahn E, Classen-Linke I, Kusche M, Beier HM, Traub O, Gru“mmer R \& Winterhager E 1995 Expression of gap junction connexins in the human endometrium throughout the menstrual cycle. Human Reproduction 10 2666-2670. (https://doi.org/10.1093/oxfordjournals. humrep.a135764)

Jetten AM, De Luca LM, Nelson K, Schroeder W, Burlingame S \& Fujimoto W 1996 Regulation of cornifin alpha expression in (c) 2018 Society for Endocrinology Published by Bioscientifica Ltd. Printed in Great Britain 
the vaginal and uterine epithelium by estrogen and retinoic acid. Molecular and Cellular Endocrinology 123 7-15. (https://doi. org/10.1016/0303-7207(96)03871-3)

Kambhampati S, Li Y, Verma A, Sassano A, Majchrzak B, Deb DK, Parmar S, Giafis N, Kalvakolanu DV, Rahman A et al. 2003 Activation of protein kinase $\mathrm{C}$ by all-transretinoic acid. Journal of Biological Chemistry 278 32544-32551. (https://doi.org/10.1074/jbc. M301523200)

Kastner P, Mark M, Ghyselinck N, Krezel W, Dupé V, Grondona JM \& Chambon P 1997 Genetic evidence that the retinoid signal is transduced by heterodimeric RXR/RAR functional units during mouse development. Development 124 313-326.

Katzenellenbogen BS \& Korach KS 1997 A new actor in the estrogen receptor drama - enter ER-beta. Endocrinology 138 861-862. (https://doi.org/10.1210/endo.138.3.5080)

Kawaguchi R, Yu J, Honda J, Hu J, Whitelegge H, Ping P, Wita P, Bok D \& Sun H 2007 A membrane receptor for retinol binding protein mediates cellular uptake of vitamin A. Science 315 820-825. (https://doi.org/10.1126/science.1136244)

Kawaguchi R, Zhong M, Kassai M, Ter-Stepanian M \& Sun H 2015. Vitamin A transport mechanism of the multitransmembrane cell-surface receptor STRA6. Membranes 5 425-453. (https://doi. org/10.3390/membranes5030425)

Kennedy S, Bergqvist A, Chapron C, D'Hooghe T, Dunselman G, Greb R, Hummelshoj L, Prentice A, Saridogan E, ESIGf Endometriosis \& EGD Group 2005 ESHRE guideline for the diagnosis and treatment of endometriosis. Human Reproduction 20 2698-2704. (https://doi. org/10.1093/humrep/dei135)

Kimber SJ 2005 Leukaemia inhibitory factor in implantation and uterine biology. Reproduction 130 131-145. (https://doi.org/10.1530/ rep.1.00304)

Kitareewan S, Pitha-Rowe I, Sekula D, Lowrey CH, Nemeth MJ, Golub TR, Freemantle SJ \& Dmitrovsky E 2002 UBE1L is a retinoid target that triggers PML/RARalpha degradation and apoptosis in acute promyelocytic leukemia. PNAS 99 3806-3811. (https://doi. org/10.1073/pnas.052011299)

Klemmt PA, Carver JG, Kennedy SH, Koninckx PR \& Mardon HJ 2006 Stromal cells from endometriotic lesions and endometrium from women with endometriosis have reduced decidualization capacity. Fertility and Sterility 85 564-572. (https://doi.org/10.1016/j. fertnstert.2005.08.046)

Kommagani R, Szwarc MM, Kovanci E, Gibbons WE, Putluri N, Maity S, Creighton CJ, Sreekumar A, DeMayo FJ, Lydon JP, et al. 2013 Acceleration of the glycolytic flux by steroid receptor coactivator- 2 is essential for endometrial decidualization. PLoS Genetics 9 e1003900. (https://doi.org/10.1371/journal.pgen.1003900)

Kumarendran M, Loughney A, Prentice A, Thomas E \& Redfern C 1996 Nuclear retinoid receptor expression in normal human endometrium throughout the menstrual cycle. Molecular Human Reproduction 2 123-129. (https://doi.org/10.1093/molehr/2.2.123)

Kupker W, Schultze-Mosgau A \& Diedrich K 1998 Paracrine changes in the peritoneal environment of women with endometriosis. Human Reproduction Update 4 719-723. (https://doi.org/10.1093/ humupd/4.5.719)

Kurita T, Lee KJ, Cooke PS, Taylor JA, Lubahn DB \& Cunha GR 2000 Paracrine regulation of epithelial progesterone receptor by estradiol in the mouse female reproductive tract. Biology of Reproduction $\mathbf{6 2}$ 821-830. (https://doi.org/10.1093/biolreprod/62.4.821)

Kuroda K, Venkatakrishnan R, Salker MS, Lucas ES, Shaheen F, Kuroda M, Blanks A, Christian M, Quenby S \& Brosens JJ 2013 Induction of 11 beta-HSD 1 and activation of distinct mineralocorticoid receptor- and glucocorticoid receptor-dependent gene networks in decidualizing human endometrial stromal cells. Molecular Endocrinology 27 192-202. (https://doi.org/10.1210/me.2012-1247)
Lawn AM, Wilson EW \& Finn CA 1971 The ultrastructure of human decidual and predecidual cells. Journal of Reproduction and Infertility $\mathbf{2 6}$ 85-90. (https://doi.org/10.1530/jrf.0.0260085)

Laws MJ, Taylor RN, Sidell N, DeMayo FJ, Lydon JP, Gutstein DE, Bagchi MK \& Bagchi IC 2008 Gap junction communication between uterine stromal cells plays a critical role in pregnancy-associated neovascularization and embryo survival. Development 135 2659-2668. (https://doi.org/10.1242/dev.019810)

Lessey BA, Lebovic DI \& Taylor RN 2013 Eutopic endometrium in women with endometriosis: 'ground zero' for the study of implantation defects. Seminars in Reproductive Medicine 31 109-124. (https://doi. org/10.1055/s-0032-1333476)

Li XH \& Ong DE 2003 Cellular retinoic acid-binding protein II gene expression is directly induced by estrogen, but not retinoic acid, in rat uterus. Journal of Biological Chemistry 278 35819-35825. (https://doi. org/10.1074/jbc.M302551200)

Li XH, Kakkad B \& Ong DE 2004 Estrogen directly induces expression of retinoic acid biosynthetic enzymes, compartmentalized between the epithelium and underlying stromal cells in rat uterus. Endocrinology 145 4756-4762. (https://doi.org/10.1210/en.2004-0514)

Lin M, Zhang M, Abraham M, Smith SM \& Napoli JL 2003 Mouse retina dehydrogenase 4 (RALDH4), molecular cloning, cellular expression, and activity in 9-cis-retinoic acid biosynthesis in intact cells. Journal of Biological Chemistry 278 9856-9861. (https://doi.org/10.1074/jbc. M211417200)

Loudig O, Babichuk C, White J, Abu-Abed S, Mueller C \& Petkovich M 2000 Cytochrome P450RAI(CYP26) promoter: a distinct composite retinoic acid response element underlies the complex regulation of retinoic acid metabolism. Molecular Endocrinology 14 1483-1497. (https://doi.org/10.1210/mend.14.9.0518)

Loudig O, Maclean GA, Dore NL, Luu L \& Petkovich M 2005 Transcriptional co-operativity between distant retinoic acid response elements in regulation of Cyp26A1 inducibility. Biochemical Journal 392 241-248. (https://doi.org/10.1042/BJ20050874)

Loughney AD \& Redfern CP 1995 Menstrual cycle related differences in the proliferative responses of cultured human endometrial stromal cells to retinoic acid. Journal of Reproduction and Infertility $\mathbf{1 0 5}$ 153-159. (https://doi.org/10.1530/jrf.0.1050153)

Loughney A, Kumarendran M, Thomas E \& Redfern C 1995 Variation in the expression of cellular retinoid binding proteins in human endometrium throughout the menstrual cycle. Human Reproduction 10 1297-1304. (https://doi.org/10.1093/oxfordjournals.humrep.a136137)

Ma L, Benson GV, Lim H, Dey SK \& Maas RL 1998 Abdominal B (AbdB) Hoxa genes: regulation in adult uterus by estrogen and progesterone and repression in müllerian duct by the synthetic estrogen diethylstilbestrol (DES). Developmental Biology 197 141-154. (https://doi.org/10.1006/dbio.1998.8907)

Ma JJ, Han BC, Yang Y \& Peng JP 2012 Retinoic acid synthesis and metabolism are concurrent in the mouse uterus during periimplantation. Cell and Tissue Research 350 525-537. (https://doi. org/10.1007/s00441-012-1507-4)

Mantena SR, Kannan A, Cheon YP, Li Q, Johnson PF, Bagchi IC \& Bagchi MK 2006 C/EBPbeta is a critical mediator of steroid hormone regulated cell proliferation and differentiation in the uterine epithelium and stroma. PNAS 103 1870-1875. (https://doi. org/10.1073/pnas.0507261103)

Matsumoto H \& Sato E 2006 Uterine angiogenesis during implantation and decidualization in mice. Reproductive Medicine and Biology $\mathbf{5}$ 81-86. (https://doi.org/10.1007/BF03016143)

Matsumoto H, Ma WG, Daikoku T, Zhao X, Paria BC, Das SK, Trzaskos JM \& Dey SK 2002 Cyclooxygenase-2 differentially directs uterine angiogenesis during implantation in mice. Journal of Biological Chemistry 277 29260-29267. (https://doi.org/10.1074/jbc. M203996200) (c) 2018 Society for Endocrinology Published by Bioscientifica Ltd. Printed in Great Britain 
Matsumoto H, Fukui E \& Yoshizawa M 2007 Uterine angiogenesis during implantation in mice. Journal of Mammalian Ova Research 24 45-49. (https://doi.org/10.1274/jmor.24.45)

Mendelsohn C, Lohnes D, Décimo D, Lufkin T, LeMeur M, Chambon P \& Mark M 1994 Function of the retinoic acid receptors (RARs) during development (II). Multiple abnormalities at various stages of organogenesis in RAR double mutants. Development 120 2749-2771.

Mowa CN \& Iwanaga T $2000 a$ Developmental changes of the oestrogen receptor-alpha and -beta mRNAs in the female reproductive organ of the rat: an analysis by in situ hybridization. Journal of Endocrinology 167 363-369. (https://doi.org/10.1677/joe.0.1670363)

Mowa CN \& Iwanaga T $2000 b$ Differential distribution of oestrogen receptor-alpha and -beta mRNAs in the female reproductive organ of rats as revealed by in situ hybridization. Journal of Endocrinology 165 59-66. (https://doi.org/10.1677/joe.0.1650059)

Nakagawa S, Fujii T, Yokoyama G, Kazanietz MG, Yamana H \& Shirouzu K 2003 Cell growth inhibition by all-trans retinoic acid in SKBR-3 breast cancer cells: involvement of protein kinase $\mathrm{C}$ and extracellular signal-regulated kinase mitogen-activated protein kinase. Molecular Carcinogenesis 38 106-116 (https://doi.org/10.1002/mc.10150)

Nakajima T, Hayashi S, Iguchi T \& Sato T 2011a The role of fibroblast growth factors on the differentiation of vaginal epithelium of neonatal mice. Differentiation 82 28-37. (https://doi.org/10.1016/j. diff.2011.03.005)

Nakajima T, Iguchi T \& Sato T $2011 b$ Involvement of activin signaling in abnormalities of mouse vagina exposed neonatally to diethylstilbestrol. Cell and Tissue Research 344 527-538. (https://doi. org/10.1007/s00441-011-1161-2)

Nakajima T, Iguchi T \& Sato T 2016 Retinoic acid signaling determines the fate of uterine stroma in the mouse Müllerian duct. PNAS 113 14354-14359. (https://doi.org/10.1073/pnas.1608808113)

Napoli JL 1999 Interactions of retinoid binding proteins and enzymes in retinoid metabolism. Biochimica et Biophysica Acta 1440 139-162. (https://doi.org/10.1016/S1388-1981(99)00117-1)

Napoli JL 2012 Physiological insights into all-trans-retinoic acid biosynthesis. Biochimica et Biophysica Acta 1821 152-167 (https://doi. org/10.1016/j.bbalip.2011.05.004)

Napoli JL 2016 Functions of intracellular retinoid binding-proteins. SubCellular Biochemistry 81 21-76. (https://doi.org/10.1007/978-94-0240945-1_2)

Nasu K, Yuge A, Tsuno A, Nishida M \& Narahara H 2009 Involvement of resistance to apoptosis in the pathogenesis of endometriosis. Histology and Histopathology 24 1181-1192. (https://doi.org/10.14670/ HH-24.1181)

Niwa H, Burdon T, Chambers I \& Smith A 1998 Self-renewal of pluripotent embryonic stem cells is mediated via activation of STAT3. Genes and Development 12 2048-2060. (https://doi.org/10.1101/ gad.12.13.2048)

Nnoaham KE, Hummelshoj L, Webster P, d'Hooghe T, de Cicco Nardone F, de Cicco Nardone C, Jenkinson C, Kennedy SH, Zondervan KT \& World Endometriosis Research Foundation Global Study of Women's Health Consortium 2011 Impact of endometriosis on quality of life and work productivity: a multicenter study across ten countries. Fertility and Sterility 96 366.e8-373.e8. (https://doi. org/10.1016/j.fertnstert.2011.05.090)

Noy N 2000 Retinoid-binding proteins: mediators of retinoid action. Biochemical Journal 348 481-495. (https://doi.org/10.1042/bj3480481)

Nozaki Y, Yamagata T, Sugiyama M, Ikoma S, Kinoshita K \& Funauchi M 2006 Anti-inflammatory effect of all-trans-retinoic acid in inflammatory arthritis. Journal of Clinical Immunology 119 272-279. (https://doi.org/10.1016/j.clim.2005.11.012)

Oh SY, Grupen CG \& Murray AW 1991 Phorbol ester induces phosphorylation and down-regulation of connexin 43 in WB cells. Biochimica et Biophysica Acta 1094 243-245. (https://doi. org/10.1016/0167-4889(91)90016-Q)
Omwandho CO, Konrad L, Halis G, Oehmke F \& Tinneberg HR. 2010 Role of TGF-betas in normal human endometrium and endometriosis. Human Reproduction 25 101-109. (https://doi.org/10.1093/humrep/ dep382)

Oosterlynck DJ, Meuleman C, Waer M \& Koninckx PR 1994 Transforming growth factor- $\beta$ activity is increased in peritoneal fluid from women with endometriosis. Obstetrics and Gynecology 83 287-292.

Osteen KG, Igarashi TM \& Bruner-Tran KL 2003 Progesterone action in the human endometrium: induction of a unique tissue environment which limits matrix metalloproteinase (MMP) expression. Frontiers in Bioscience 8 78-86. (https://doi.org/10.2741/938)

Osteen KG, Bruner-Tran KL \& Eisenberg E 2005 Endometrial biology and the etiology of endometriosis. Fertility and Sterility 84 33-34. (https://doi.org/10.1016/j.fertnstert.2005.01.124)

Ozaki R, Kuroda K, Ikemoto Y, Ochiai A, Matsumoto A, Kumakiri J, Kitade M, Itakura A, Muter J, Brosens JJ, et al. 2017 Reprogramming of the retinoic acid pathway in decidualizing human endometrial stromal cells. PLOS ONE 12 e0173035. (https://doi.org/10.1371/ journal.pone.0173035)

Pavone ME, Reierstad S, Sun H, Milad M, Bulun SE \& Cheng YH 2010 Altered retinoid uptake and action contributes to cell survival in endometriosis. Journal of Clinical Endocrinology and Metabolism 95 E300-E309. (https://doi.org/10.1210/jc.2010-0459)

Pavone ME, Dyson M, Reirstad S, Pearson E, Ishikawa H, Cheng YH \& Bulun SE 2011 Endometriosis expresses a molecular pattern consistent with decreased retinoid uptake, metabolism and action. Human Reproduction 26 2157-2164. (https://doi.org/10.1093/humrep/der172)

Pavone ME, Malpani S, Dyson M \& Bulun SE 2017 Altered retinoid signaling compromises decidualization in human endometriotic stromal cells. Reproduction 154 107-116. (https://doi.org/10.1530/ REP-16-0592)

Pierzchalski K, Taylor RN, Nezhat C, Jones JW, Napoli JL, Yang G, Kane MA \& Sidell N 2014 Retinoic acid biosynthesis is impaired in human and murine endometriosis. Biology of Reproduction 9184. (https://doi.org/10.1095/biolreprod.114.119677)

Ponnamperuma RM, Kirchhof SM, Trifiletti L \& DeLuca LM 1999 Ovariectomy increases squamous metaplasia of the uterine horns and suvival of SENCAR mice fed a vitamin A-deficient diet. American Journal of Clinical Nutrition 70 502-508.

Prentice A, Matthews CJ, Thomas EJ \& Redfern CP 1992 The expression of retinoic acid receptors in cultured human endometrial stromal cells and effects of retinoic acid. Human Reproduction 7 692-700. (https://doi.org/10.1093/oxfordjournals.humrep.a137721)

Punyadeera C, Verbost P \& Groothuis P 2003 Oestrogen and progestin responses in human endometrium. Journal of Steroid Biochemistry and Molecular 84 393-410. (https://doi.org/10.1016/S09600760(03)00061-X)

Quadro L, Blaner WS, Hamberger L, Novikoff PM, Vogel S, Piantedosi R, Gottesman ME \& Colantuoni V 2004 The role of extrahepatic retinol binding protein in the mobilization of retinoid stores. Journal of Lipid Research 45 1975-1982. (https://doi.org/10.1194/jlr.M400137-JLR200)

Regidor P-A, Regidor M, Schindler AE \& Winterhager E 1997 Aberrant expression pattern of gap junction connexins in endometriotic tissues. Molecular Human Reproduction 3 375-381. (https://doi. org/10.1093/molehr/3.5.375)

Rochette-Egly C 2014 Retinoic acid signaling and mouse embryonic stem cell differentiation: cross talk between genomic and non-genomic effects of RA. Biochimica et Biophysica Acta 1851 66-75. (https://doi. org/10.1016/j.bbalip.2014.04.003)

Ross SA, McCaffery PJ, Drager UC \& De Luca LM 2000 Retinoids in embryonal development. Physiological Reviews 80 1021-1054. (https://doi.org/10.1152/physrev.2000.80.3.1021)

Ruberte E, Friederich V, Morriss-Kay G \& Chambon P 1992. Differential distribution patterns of CRABPI and CRABPII transcripts during mouse embryogenesis. Development 115 973-987. 
Rühl R, Fritzsche B, Vermot J, Niederreither K, Neumann U, Schmidt A, Schweigert FJ \& Dollé P 2006 Regulation of expression of the retinoic acid-synthesising enzymes retinaldehyde dehydrogenases in the uteri of ovariectomised mice after treatment with oestrogen, gestagen and their combination. Reproduction, Fertility and Development 18 339-345. (https://doi.org/10.1071/rd05056)

Saito A, Sugawara A, Uruno A, Kudo M, Kagechika H, Sato Y, Owada Y, Kondo H, Sato M, Kurabayashi M, et al. 2007 All-trans retinoic acid induces in vitro angiogenesis via retinoic acid receptor: possible involvement of paracrine effects of endogenous vascular endothelial growth factor signaling. Endocrinology 148 1412-1423. (https://doi. org/10.1210/en.2006-0900)

Sawatsri S, Desai N, Rock JA \& Sidell N 2000 Retinoic acid suppresses interleukin-6 production in human endometrial cells. Fertility and Sterility 73 1012-1019. (https://doi.org/10.1016/S00150282(00)00483-0)

Schug TT, Berry DC, Shaw NS, Travis SN \& Noy N 2007 Opposing effects of retinoic acid on cell growth result from alternate activation of two different nuclear receptors. Cell 129 723-733. (https://doi. org/10.1016/j.cell.2007.02.050)

Schug TT, Berry DC, Toshkov IA, Cheng L, Nikitin AY \& Noy N 2008 Overcoming retinoic acid-resistance of mammary carcinomas by diverting retinoic acid from PPAR/to RAR. PNAS 105 7546-7551. (https://doi.org/10.1073/pnas.0709981105)

Sharpe-Timms KL 2001 Endometrial anomalies in women with endometriosis. Annals of the New York Academy of Sciences 943 131-147. (https://doi.org/10.1111/j.1749-6632.2001.tb03797.x)

Sidell N, Han SW \& Parthasarathy S 2002 Regulation and modulation of abnormal immune responses in endometriosis. Annals of the New York Academy of Sciences 955 159-173. (https://doi. org/10.1111/j.1749-6632.2002.tb02777.x)

Sidell N, Feng Y, Hao L, Wu J, Yu J, Kane MA, Napoli JL \& Taylor RN 2010 Retinoic acid is a cofactor for translational regulation of vascular endothelial growth factor in human endometrial stromal cells. Molecular Endocrinology 24 148-160. (https://doi.org/10.1210/ me.2009-0155)

Sokalska A, Anderson M, Villanueva J, Ortega I, Bruner-Tran KL, Osteen KG \& Duleba AJ 2013 Effects of simvastatin on retinoic acid system in primary human endometrial stromal cells and in a chimeric model of human endometriosis. Journal of Clinical Endocrinology and Metabolism 98 E463-E471. (https://doi.org/10.1210/jc.2012-3402)

Solan JL \& Lampe PD 2009 Connexin43 phosphorylation: structural changes and biological effects. Biochemical Journal 419 261-272. (https://doi.org/10.1042/BJ20082319)

Spencer TE, Dunlap KA \& Filant J 2012 Comparative developmental biology of the uterus: insights into mechanisms and developmental disruption. Molecular and Cellular Endocrinology 354 34-53. (https://doi.org/10.1016/j.mce.2011.09.035)

Stahl W \& Sies H 1998 The role of carotenoids and retinoids in gap junctional communication. International Journal for Vitamin and Nutrition Research 68 354-359.

Stewart CL 1994 Leukaemia inhibitory factor and the regulation of preimplantation development of the mammalian embryo. Molecular Reproduction and Development 39 233-238. (https://doi.org/10.1002/ mrd.1080390217)

Stilley JA, Birt JA \& Sharpe-Timms KL 2012 Cellular and molecular basis for endometriosis-445 associated infertility. Cell and Tissue Research 349 849-862. (https://doi.org/10.1007/s00441-011-1309-0)

Suzuki A, Watanabe H, Mizutani T, Sato T, Ohta Y \& Iguchi T 2006 Global gene expression in mouse vaginae exposed to diethylstilbestrol at different ages. Experimental Biology and Medicine 231 632-640. (https://doi.org/10.1177/153537020623100518)

Suzuki A, Urushitani H, Sato T, Kobayashi T, Watanabe H, Ohta Y \& Iguchi T 2007 Gene expression change in the Müllerian duct of the mouse fetus exposed to diethylstilbestrol in utero. Experimental Biology and Medicine 232 503-514.
Tang B, Culler S \& Gurpide E 1993 Cyclic adenosine 3', $5^{\prime}$-monophosphate induces prolactin expression in stromal cells isolated from human proliferative endometrium. Endocrinology 133 2197-2203. (https://doi.org/10.1210/endo.133.5.8404671)

Tanmahasamut P \& Sidell N 2005 Up-regulation of gap junctional intercellular communication and connexin 43 expression by retinoic acid in human endometrial stromal cells. Journal of Clinical Endocrinology and Metabolism 90 4151-4156. (https://doi.org/10.1210/ jc.2004-0663)

Taylor RN 2010 Classical and neo-classical concepts in the etiology of endometriosis. In Proceedings of the IFFS 20th World Congress on Fertility and Sterility, pp 70-73. Eds B Hedon, L Mettler \& H-R Tinneberg. Munich, Germany: Lukon.

Taylor RN, Kane MA \& Sidell N 2015 Pathogenesis of endometriosis: roles of retinoids and inflammatory pathways. Seminars in Reproductive Medicine 33 246-256. (https://doi.org/10.1055/s-0035-1554920)

Toma S, Isnardi L, Raffo P, Dastoli G, De Francisci E, Riccardi L, Palumbo R \& Bollag W 1997 Effects of ALL-trans-retinoic acid and 13-cis-retinoic acid on breast-cancer cell lines: growth inhibition and apoptosis induction. International Journal of Cancer 70 619-627. (https://doi.org/10.1002/(SICI)1097-0215(19970304)70:5<619::AIDIJC21>3.0.CO;2-6)

Ulven SM, Gundersen TE, Weedon MS, Landaas VO, Sakhi AK, Fromm SH, Geronimo BA, Moskaug JO \& Blomhoff R 2000 Identification of endogenous retinoids, enzymes, binding proteins, and receptors during early postimplantation development in mouse: important role of retinal dehydrogenase type 2 in synthesis of alltrans-retinoic acid. Developmental Biology 220 379-391. (https://doi. org/10.1006/dbio.2000.9634)

Vallet JL, Christenson RK, Bartol FF \& Wiley AA 1995 Effect of treatment with retinyl palmitate, progesterone, oestradiol and tamoxifen on secretion of a protein similar to retinol-binding protein during uterine gland development in neonatal pigs. Journal of Reproduction and Infertility 103 189-197. (https://doi.org/10.1530/jrf.0.1030189)

Verma AK 1988 Inhibition of tumor promoter 12-O-tetradecanoylphorbol-13-acetate-induced synthesis of epidermal ornithine decarboxylase messenger RNA and diacylglycerol-promoted mouse skin tumor formation by retinoic acid. Cancer Research $\mathbf{4 8}$ 2168-2173.

Vermot J, Fraulob V, Dolle P \& Niederreither K 2000 Expression of enzymes synthesizing (aldehyde dehydrogenase 1 and reinaldehyde dehydrogenase 2) and metabolizaing (Cyp26) retinoic acid in the mouse female reproductive system. Endocrinology 141 3638-3645. (https://doi.org/10.1210/endo.141.10.7696)

Wang H \& Dey SK 2006 Roadmap to embryo implantation: clues from mouse models. Nature Reviews Genetics 7 185-199. (https://doi. org/10.1038/nrg1808)

Wang X, Sperkova Z \& Napoli JL 2001 Analysis of mouse retinal dehydrogenase type 2 promoter and expression. Genomics $\mathbf{7 4}$ 245-250. (https://doi.org/10.1006/geno.2001.6546)

Wardlaw SA, Bucco RA, Zheng WL \& Ong DE 1997 Variable expression of cellular retinol- and cellular retinoic acid-binding proteins in the rat uterus and ovary during the estrous cycle. Biology of Reproduction $\mathbf{5 6}$ 125-132. (https://doi.org/10.1095/biolreprod56.1.125)

Warn-Cramer BJ, Lampe PD, Durata WE, Kanemitsu MY, Loo LWM, Eckhart W \& Lau AF 1996 Characterization of the mitogen-activated protein kinase phosphorylation sites on the connexin-43 gap junction protein. Journal of Biological Chemistry 271 3779-3786. (https://doi.org/10.1074/jbc.271.7.3779)

Wieser F, Wu J, Shen Z, Taylor RN \& Sidell N 2012 Retinoic acid suppresses growth of lesions, inhibits peritoneal cytokine secretion, and promotes macrophage differentiation in an immunocompetent mouse model of endometriosis. Fertility and Sterility 97 1430-1437. (https://doi.org/10.1016/j.fertnstert.2012.03.004)

Wilson JG \& Warkany J 1948 Malformations in the genito-urinary tract induced by maternal vitamin A deficiency in the rat. American 
Journal of Clinical Nutrition 83 357-407. (https://doi.org/10.1002/ aja.1000830303)

Winterhager E \& Kidder GM 2015 Gap junction connexins in female reproductive organs: implications for women's reproductive health. Human Reproduction Update 21 340-352. (https://doi.org/10.1093/ humupd/dmv007)

Winterhager E, Grümmer R, Mavrogianis PA, Jones CJP, Hastings JM \& Fazleabas AT 2009 Connexin expression pattern in the endometrium of baboons is influenced by hormonal changes and the presence of endometriotic lesions. Molecular Human Reproduction 15 645-652. (https://doi.org/10.1093/molehr/gap060)

Wu L \& Ross AC 2010 Acidic retinoids synergize with vitamin A to enhance retinol uptake and STRA6, LRAT, and CYP26B1 expression in neonatal lung. Journal of Lipid Research 51 378-387. (https://doi. org/10.1194/jlr.M001222)

Wu J, Taylor RN \& Sidell N 2013 Retinoic acid regulates gap junction intercellular communication in human endometrial stromal cells through modulation of the phosphorylation status of connexin 43. Journal of Cellular Physiology 228 903-910. (https://doi.org/10.1002/ jcp.24241)

Xia HF, Ma JJ, Sun J, Yang Y \& Peng JP 2010 Retinoic acid metabolizing enzyme CYP26A1 is implicated in rat embryo implantation. Human Reproduction 25 2985-2998. (https://doi.org/10.1093/humrep/deq268)

Yamagata Y, Nishino K, Takaki E, Sato S, Maekawa R, Nakai A \& Sugino N 2014 Genome-wide DNA methylation profiling in cultured eutopic and ectopic endometrial stromal cells. PLoS ONE 9 e83612. (https://doi.org/10.1371/journal.pone.0083612)

Yamagata Y, Takaki E, Shinagawa M, Okada M, Jozaki K, Lee L, Sato S, Maekawa R, Taketani T, Asada H et al. 2015 Retinoic acid has the potential to suppress endometriosis development. Journal of Ovarian Research 8 49. (https://doi.org/10.1186/s13048-015-0179-6)

Yamanouchi H, Umezu T \& Tomooka Y 2010 Reconstruction of oviduct and demonstration of epithelial fate determination in mice. Biology of Reproduction 82 528-533. (https://doi.org/10.1095/ biolreprod.109.078329)

Yamasaki H, Krutovskikh V, Mesnil M, Tanaka T, Zaidan-Dagli ML \& Omori Y 1999 Role of connexin (gap junction) genes in cell growth control and carcinogenesis. Comptes Rendus de l'Académie des Sciences - Series III - Sciences de la Vie 322 151-159. (https://doi.org/10.1016/ s0764-4469(99)80038-9)

Yu J, Wu J, Bagchi IC, Bagchi MK, Sidell N \& Taylor RN 2011 Disruption of gap junctions reduces biomarkers of decidualization and angiogenesis and increases inflammatory mediators in human endometrial stromal cell cultures. Molecular and Cellular Endocrinology 344 25-34. (https://doi.org/10.1016/j.mce.2011.04.011)

Yu J, Berga SL, Zou W, Sun HY, Johnston-MacAnanny E, Yalcinkaya T, Sidell N, Bagchi IC, Bagchi MK \& Taylor RN 2014a Gap junction blockade induces apoptosis in human endometrial stromal cells. Molecular Reproduction and Development 81 666-675. (https://doi. org $/ 10.1002 /$ mrd.22334)

Yu J, Boicea A, Barrett KL, James CO, Bagchi IC, Bagchi MK, Nezhat C, Sidell N \& Taylor RN 2014b Reduced connexin 43 in eutopic endometrium and cultured endometrial stromal cells from subjects with endometriosis. Molecular Human Reproduction 20 260-270. (https://doi.org/10.1093/molehr/gat087)

Yu J, Berga SL, Johnston-MacAnanny EB, Sidell N, Bagchi IC, Bagchi MK \& Taylor RN 2016 Endometrial stromal decidualization responds reversibly to hormone stimulation and withdrawal. Endocrinology 157 2432-2446. (https://doi. org/10.1210/en.2015-1942)

Zhang S, Lin H, Kong S, Wang S, Wang H, Wang H \& Armant DR 2013 Physiological and molecular determinants of embryo implantation. Molecular Aspects of Medicine 34 939-980. (https://doi.org/10.1016/j. mam.2012.12.011

Zheng WL \& Ong DE 1998 Spatial and temporal patterns of expression of cellular retinol-binding protein and cellular retinoic acid-binding proteins in rat uterus during early pregnancy. Biology of Reproduction 58 963-970. (https://doi.org/10.1095/ biolreprod58.4.963)

Zheng WL, Sierra-Rivera E, Luan J, Osteen KG \& Ong DE 2000 Retinoic acid synthesis and expression of cellular retinol-binding protein and cellular retinoic acid-binding protein type II are concurrent with decidualization of rat uterine stromal cells. Endocrinology 141 802-808. (https://doi.org/10.1210/endo.141.2.7323)

Received in final form 19 December 2017

Accepted 3 January 2018

Accepted Preprint published online 3 January 2018 